\title{
The Effect of $\boldsymbol{n}$-3 Fatty Acids on Glucose Homeostasis and Insulin Sensitivity
}

\author{
P. FLACHS ${ }^{1}$, M. ROSSMEISL ${ }^{1}$, J. KOPECKY ${ }^{1}$ \\ ${ }^{1}$ Department of Adipose Tissue Biology, Institute of Physiology Academy of Sciences of the Czech \\ Republic, Prague, Czech Republic
}

Received December 7, 2013

Accepted December 16, 2013

\section{Summary}

Type 2 diabetes (T2D) as well as cardiovascular disease (CVD) represent major complications of obesity and associated metabolic disorders (metabolic syndrome). This review focuses on the effects of long-chain $n-3$ polyunsaturated fatty acids (omega-3) on insulin sensitivity and glucose homeostasis, which are improved by omega- 3 in many animal models of metabolic syndrome, but remain frequently unaffected in humans. Here we focus on: (i) mechanistic aspects of omega-3 action, reflecting also our experiments in dietary obese mice; and (ii) recent studies analysing omega-3's effects in various categories of human subjects. Most animal experiments document beneficial effects of omega- 3 on insulin sensitivity and glucose metabolism even under conditions of established obesity and insulin resistance. Besides positive results obtained in both crosssectional and prospective cohort studies on healthy human populations, also some intervention studies in prediabetic subjects document amelioration of impaired glucose homeostasis by omega-3. However, the use of omega-3 to reduce a risk of new-onset diabetes in prediabetic subjects still remains to be further characterized. The results of a majority of clinical trials performed in T2D patients suggest that omega-3 have none or marginal effects on metabolic control, while effectively reducing hypertriglyceridemia in these patients. Despite most of the recent randomized clinical trials do not support the role of omega-3 in secondary prevention of CVD, this issue remains still controversial. Combined interventions using omega-3 and antidiabetic or hypolipidemic drugs should be further explored and considered for treatment of patients with T2D and other diseases.

\section{Key words}

Diabetes • Obesity • Inflammation • Metabolic syndrome • Omega-3 fatty acids

\section{Corresponding author}

J. Kopecky, Department of Adipose Tissue Biology, Institute of Physiology of the Academy of Sciences of the Czech Republic, v.v.i., Videnska 1083, 14220 Prague 4, Czech Republic. Fax: +420 241062599. E-mail: kopecky@biomed.cas.cz

\section{Introduction}

Type 2 diabetes (T2D) as well as cardiovascular disease (CVD) represent major complications of obesity and associated metabolic disorders, which are clustered in the metabolic syndrome (including namely dyslipidemia, impaired insulin sensitivity and hypertension). The fundamental problem in the prevention and treatment of $\mathrm{T} 2 \mathrm{D}$ is a maintenance and restoration of insulin sensitivity in target tissues, which is disturbed already in prediabetic subjects. Optimal strategies in the prevention of obesity and T2D are always based on a healthy lifestyle, including increased physical activity and proper nutrition. These manipulations were sufficient to lower the incidence of T2D in patients with impaired glucose tolerance (IGT) by $60 \%$ (Tuomilehto et al. 2001, Knowler et al. 2002).

Long-chain polyunsaturated fatty acids (FA) of $n-3$ series (omega-3), which are abundant in marine fish, namely docosahexaenoic acid (DHA, 22:6n-3), eicosapentaenoic acid (EPA, 20:5n-3), and 
docosapentaenoic acid (DPA, 22:5n-3); for the nomenclature, see Table 1), act as natural hypolipidemic and anti-inflammatory agents and ameliorate various aspects of the metabolic syndrome (reviewed in Flachs et al. 2009, Mozaffarian et al. 2013). However, while omega-3 affect different components of the syndrome to various extent, their effects are dose-dependent and involve complex mechanisms of action (Table 2 and below).

Table 1. Nomenclature of omega-3.

\begin{tabular}{|c|c|c|c|c|}
\hline Names & & & Abbreviations & \\
\hline Trivial & Chemical & Carboxyl-reference & Omega-reference & Other \\
\hline Linolenic acid & $\begin{array}{l}\text { 9,12,15- } \\
\text { octadecenoic acid }\end{array}$ & $18: 3 \Delta 91215$ & $\begin{array}{l}18: 3 \mathrm{n}-3 \\
18: 3 \omega 3\end{array}$ & ALA \\
\hline Eicosapentaenoic acid & $\begin{array}{l}5,8,11,14,17- \\
\text { eicosapentaenoic acid }\end{array}$ & $20: 5 \Delta 58111417$ & $\begin{array}{l}20: 5 n-3 \\
20: 5 \omega 3\end{array}$ & EPA \\
\hline Docosapentaenoic acid & $\begin{array}{l}\text { 7,10,13,16,19- } \\
\text { docosapentaenoic acid }\end{array}$ & $22: 5 \Delta 710131619$ & $\begin{array}{l}22: 5 n-3 \\
22: 5 \omega 3\end{array}$ & DPA \\
\hline Docosahexaenoic acid & $\begin{array}{l}4,8,12,15,19- \\
\text { docosahexaenoic acid }\end{array}$ & $22: 6 \Delta 48121519$ & $\begin{array}{l}22: 6 n-3 \\
22: 6 \omega 3\end{array}$ & DHA \\
\hline
\end{tabular}

We focus here on the controversial topic related to the beneficial effects of omega- 3 on insulin sensitivity and glucose homeostasis, which are documented in many animal models of metabolic syndrome, but less frequently observed in humans. The subject of this review has been covered in several articles in the past (Friedberg et al. 1998, Montori et al. 2000, Delarue et al. 2004, Lombardo and Chicco 2006), however a synopsis of a more recent knowledge is missing. We focus here on (a) mechanistic aspects of omega-3 action, reflecting also our studies in dietary obese mice; (b) recent studies regarding omega-3 effects in humans; and (c) possible reasons underlying the contrasting results in the animal and human studies.

\section{Metabolism of essential fatty acids}

Mammals cannot synthesize FA of $n-6$ and $n-3$ series, which contain double-bonds at C-6 and C-3 from the methyl end of the molecule, respectively. Polyunsaturated FA are exclusively synthesized by cells of plant origin. The most plentiful source of $n-3$ polyunsaturated fatty acid is marine phytoplankton, a major component of marine food chain. Precursors for the synthesis of long-chain polyunsaturated FA of $n-6$ series (omega-6) and omega-3 in mammals are linoleic acid (LA, 18:2n-6) and $\alpha$-linolenic acid (ALA; 18:3n-3), respectively. Although LA and ALA give rise to different metabolites, the enzymes that participate in the formation of those metabolites are the same. In fact, LA and ALA compete for the enzyme $\Delta 6$ desaturase that is the first metabolic step necessary for their further conversion. Excessive amount of LA slows down the formation of EPA and DHA (i.e. omega-3). Even without this inhibitory effect the synthesis of EPA and DHA from their precursor ALA proceeds relatively slowly, therefore increased intake of EPA and DHA could have an effect even if the content of ALA in the diet is relatively high. EPA a DHA are interconvertable (Smith 2005). An excess of ALA inhibits LA metabolism, in particular the synthesis of arachidonic acid (AA; 20:4n-6; reviewed in Flachs et al. 2009). Omega-3 and omega-6 represent the fundamental components of phospholipids in cellular membranes and surface layer of intracellular lipid droplets. Polyunsaturated FA are usually located at the $s n-2$ position, while saturated or monounsaturated FA are bound to $s n-1$ position of the phospholipid molecules. Many effects of omega- 3 and omega- 6 depend on the formation of their active metabolites, oxylipins (the oxidation products - prostaglandins, leukotriens, protectins, etc.) and other lipid mediators (N-acylethanolamines, endocannabinoids, etc.). These molecules are generated from membrane phospholipids and act in both autocrine and paracrine manners (reviewed in Flachs et al. 2009, Hansen and Diep 2009, Wang and Ueda 2009, Rossmeisl et al. 2012, Flachs et al. 2013). The synthesis of oxylipins mostly depends on the activity of cyclooxygenase (type 1 and 2), for which AA is a ,better" substrate than EPA, and the activity of lipoxygenase, whose preferences for AA and EPA are 
opposite compared to cyclooxygenase (Smith 2005). AA and EPA compete for cyclooxygenase and both EPA and DHA directly inhibit the activity of this enzyme. Therefore, a relatively mild elevation of the omega- 3 content significantly slows down the synthesis of eicosanoids from AA. Based on this mechanism, it is possible to explain many beneficial effects of omega-3, first of all the suppression of inflammation, blood clotting, tumour and fat cell proliferation, and also relieve of pain. The discovery of pro-resolving and antiinflammatory omega-3-derived lipid mediators called resolvins (E-resolvins and D-resolvins), protectins and maresins opened a new field concerning the active mechanisms involved in resolution of inflammation (Serhan and Petasis 2011). Similarly,
N-acylethanolamines EPEA and DHEA, which are derived from EPA and DHA respectively, have antiinflammatory effects (Balvers et al. 2012). Everlasting increases in the amount of LA (i.e. omega-6) in human diet prevent favourable anti-inflammatory and metabolic effects of omega-3 and facilitate the accumulation of adipose tissue (Blasbalg et al. 2011, Alvheim et al. 2012; and see below). This is also the reason why beneficial effects of ALA (i.e. omega-3) become apparent when the diet is based on animal fats with a relatively low content of LA rather than on regular plant oils with higher LA content. If the diet contains high amounts of LA, then it is only a supplementation with EPA and DHA, but not with ALA, that leads to a favourable effect (Storlien et al. 1991).

Table 2. Effects of omega-3 on metabolic syndrome features and associated diseases in humans.

\begin{tabular}{|c|c|c|}
\hline & Effect of omega-3 & References \\
\hline \multicolumn{3}{|l|}{ Healthy individuals } \\
\hline Plasma $T A G$ & Decrease by $20-30 \%$ & $\begin{array}{l}\text { (Bhathena et al. 1991, Williams et al. 1992, } \\
\text { Marckmann et al. 1997, Balk et al. 2004, Brady et al. } \\
\text { 2004, Faeh et al. 2005) }\end{array}$ \\
\hline Plasma insulin & No change or lowering & $\begin{array}{l}\text { (Delarue et al. 1996, Marckmann et al. 1997, Bordin et } \\
\text { al. 1998, Gustafsson et al. 1998, Lahoz et al. 1999, } \\
\text { Fontani et al. 2005) }\end{array}$ \\
\hline Glucose homeostasis & No change & $\begin{array}{l}\text { (Bhathena et al. 1991, Delarue et al. 1996, Marckmann } \\
\text { et al. 1997, Bordin et al. 1998, Lahoz et al. 1999, } \\
\text { Minihane et al. 2005) }\end{array}$ \\
\hline Blood pressure & No change or lowering & (Gustafsson et al. 1998, Lahoz et al. 1999) \\
\hline \multicolumn{3}{|c|}{ Subjects with metabolic syndrome } \\
\hline Dyslipidemia & Improvement & \multirow{2}{*}{$\begin{array}{l}\text { reviewed in (Jeppesen et al. 2013) } \\
\text { (Warner et al. 1989, Mori et al. 1999, Krebs et al. } \\
\text { 2006, Kunesova et al. 2006, Hill et al. 2007, } \\
\text { Thorsdottir et al. 2007) }\end{array}$} \\
\hline Obesity & $\begin{array}{l}\text { No change or marginal } \\
\text { improvement* }\end{array}$ & \\
\hline$I G T$ and $I R$ & Improvement & $\begin{array}{l}\text { (Ramel et al. 2008, Lopez-Alarcon et al. 2011, } \\
\text { Dangardt et al. 2012, Juarez-Lopez et al. 2013) }\end{array}$ \\
\hline New-onset diabetes & \multicolumn{2}{|l|}{ Remains to be characterized } \\
\hline \multicolumn{3}{|l|}{ Patients with T2D } \\
\hline Dyslipidemia & Improvement & $\begin{array}{l}\text { (Axelrod et al. 1994, McGrath et al. 1996, McManus } \\
\text { et al. 1996, Sirtori et al. 1997, Bosch et al. 2012) and } \\
\text { other }\end{array}$ \\
\hline$I G T$ and $I R$ & $\begin{array}{l}\text { No change or marginal } \\
\text { improvement }\end{array}$ & $\begin{array}{l}\text { (Pelikanova et al. 1993, Kesavulu et al. 2002, Bosch et } \\
\text { al. 2012, Sarbolouki et al. 2013) and other }\end{array}$ \\
\hline \multicolumn{3}{|l|}{ Patients with CVD } \\
\hline $\begin{array}{l}\text { Secondary prevention } \\
\text { of } C V D\end{array}$ & Inconsistent & $\begin{array}{l}\text { (Marchioli 1999, Kromhout et al. 2010, Rauch et al. } \\
\text { 2010, Bosch et al. 2012, Gerstein et al. 2012, Poole et } \\
\text { al. 2013, Roncaglioni et al. 2013) }\end{array}$ \\
\hline
\end{tabular}

\footnotetext{
* Especially, in combination with calorie restriction or physical exercise. For details, see the main text.
} 
Current guidelines of various societies regarding omega-3 the optimal intake in general population are reviewed in (Lorente-Cebrian et al. 2013). Specifically, the guidelines of the European Society of Cardiology and the European Association for the Study of Diabetes on the management of diabetes mellitus, prediabetes, and cardiovascular disease recommend consumption of two to three servings of fish (preferably oily) each week, corresponding to approximately $0.5 \mathrm{~g}$ EPA+DHA daily (Ryden et al. 2013).

\section{Key mechanisms underlying deterioration of insulin sensitivity}

Among the pathological states belonging to the metabolic syndrome, the strongest correlation exists between obesity and T2D (Kopelman 2000). This close link reflects several mechanisms, including: (a) impairment of insulin signaling in muscle and other tissues due to excessive accumulation of intracellular lipid products in obesity (lipotoxicity); (b) abnormal modifications of intracellular as well as extracellular proteins (such as glycated hemoglobin, HbAlc) caused by elevated levels of glucose (glucotoxicity); (c) increased production of pro-inflammatory adipokines in fat cells and endocrine and paracrine actions of these molecules.

Development of insulin resistance (IR) represents part of a vicious cycle including other metabolic disturbances, namely a compensatory increase in the production of insulin, which is required for the maintenance of glycemia in face of an impaired insulin sensitivity at the periphery, thus leading eventually to an insufficient secretion of insulin from ,exhausted“ $\beta$-cells due to a lipotoxic and glucotoxic damage. T2D develops following a prolonged period of euglycemic IR, which progresses with the development of $\beta$-cells failure. Preceding disorders of glucose metabolism, impaired fasting glucose (IFG) and IGT, are referred to as prediabetes (for the diagnostic criteria of prediabetes and T2D, see Table 3). It is also associated with a low capacity to adapt fuel oxidation to fuel availability, i.e. impaired metabolic flexibility, the key factor in the development of T2D, which is preceding the onset of overt disease (Corpeleijn et al. 2008).

Systemic IR reflects mainly the impairment of insulin action in the skeletal muscle that contributes the most to whole-body glucose consumption and impaired metabolic flexibility, but also in the liver, the site of gluconeogenesis, storage of glycogen, and release of
Table 3. World Health Organization cut-points for diagnosing prediabetes and $\mathrm{T} 2 \mathrm{D}$.

Diagnose/measurement Recommended cut-points

\section{Prediabetes \\ IFG}

Fasting plasma glucose $\quad \geq 6.1 \mathrm{mmol} / 1 \quad(\geq 110 \mathrm{mg} / \mathrm{dl})$

OGTT: 2-hour post-load $\quad<7.8 \mathrm{mmol} / 1 \quad(<140 \mathrm{mg} / \mathrm{dl})$

plasma glucose

IGT

Fasting plasma glucose $\quad<7.0 \mathrm{mmol} / 1 \quad(<126 \mathrm{mg} / \mathrm{dl})$

OGTT: 2-hour post-load $\quad \geq 7.8 \mathrm{mmol} / 1 \quad(\geq 140 \mathrm{mg} / \mathrm{dl})$

plasma glucose

\section{Diabetes}

$\mathrm{HbAlc}$

$\geq 6.5 \% \quad(48 \mathrm{mmol} / \mathrm{mol})$

Fasting plasma glucose $\quad \geq 7.0 \mathrm{mmol} / \mathrm{l} \quad(\geq 126 \mathrm{mg} / \mathrm{dl})$

OGTT: 2-hour post-load $\geq 11.1 \mathrm{mmol} / 1 \quad(\geq 200 \mathrm{mg} / \mathrm{dl})$

plasma glucose

Adapted from (Ryden et al. 2013).

glucose into the circulation. However, in spite of a relatively small contribution of adipose tissue to wholebody glucose consumption, impaired glucose transport into fat cells leads to IR in the muscle and liver (Abel et al. 2001; and see below).

The mechanism of lipotoxic impairment of insulin signaling is not understood in full. Circulating FA can activate cell-signaling pathways, which interfere with insulin action (reviewed in Glass and Olefsky 2012), while the accumulation of intracellular FA and other lipid products directly inhibits insulin signaling pathway and thus insulin-stimulated glucose transport (for review see Lowell and Shulman 2005). Better known are the mechanisms underlying the pathological storage of lipids in other tissues than adipose tissue (i.e. ectopic fat storage). These mechanisms include: (a) insufficient capacity of adipose tissue for the storage of FA due to hypertrophy of adipocytes in obesity or due to a pathological reduction of fat stores in lipodystrophy - i.e. insufficient expandability of adipose tissue (Virtue and Vidal-Puig 2010); as we have shown previously (Medrikova et al. 2011), adipose tissue expandability is higher in female as compared with male mice fed obesogenic high-fat (HF) diet, consistent with a lower risk of development of various adverse metabolic consequences of obesity in females than in males; and (b) insufficient oxidation of FA in muscle, most frequently as a result of low physical activity due to a lowering of 
mitochondrial oxidative capacity during ageing (Lowell and Shulman 2005) or due to a relative insufficiency in the face of lipid overload (Muoio and Neufer 2012).

Some adipokines (like adiponectin and leptin) increase insulin sensitivity in muscle by stimulating AMP-activated protein kinase (AMPK; Minokoshi et al. 2002, Yamauchi et al. 2002), i.e. the cellular energy sensor controlling metabolic fluxes in cells of many tissues. Elevated endocannabinoid tonus in obesity may inhibit AMPK and deteriorate its function (reviewed in Flachs et al. 2013). AMPK inhibits lipogenesis and stimulates oxidation of FA and transport of glucose into cells. AMPK is activated not only by adipokines, but also due to physical activity. Therefore, AMPK stimulates influx of glucose into muscle cells independently of insulin (Barnes and Zierath 2005). AMPK can be activated in response to metformin (Fryer et al. 2002), the common antidiabetic drug. Moreover, thiazolidinediones (TZD), used as insulin-sensitizers in the treatment of diabetic patients (e.g. pioglitazone), may stimulate AMPK activity in many tissues, rapidly and independently of PPAR $\gamma$-mediated gene transcription (Lebrasseur et al. 2006; and see below).

\section{Physiological and cellular functions of omega-3 in the context of metabolic syndrome}

Biological effects of dietary omega-3 depend on their ability to be absorbed in the intestine and transported to systemic circulation and target tissues (i.e. bioavailability), which could largely differ among individuals and may depend on many factors, including stimulation of the release of pancreatic lipases in response to bulk of dietary lipids and the lipid form of their supplementation (reviewed in Schuchardt and Hahn 2013). For instance, omega-3 supplemented as fish oil (i.e. in the form of triacylglycerols (TAG) increased the percentage of DHA+EPA (of total FA) in red blood cell membranes (omega-3 index) more efficiently than omega-3 supplemented as ethyl-esters in healthy volunteers (Neubronner et al. 2011). Furthermore, when compared with fish oils, the bioavailability of dietary DHA and especially of EPA was even better when omega-3 were supplemented as marine phospholipids, as demonstrated both in mice (Rossmeisl et al. 2012) and in humans (Maki et al. 2009, Schuchardt et al. 2011, Ulven et al. 2011). Several comparative studies in obese rodent models have suggested that improved bioavailability of omega-3 also confer their increased metabolic efficiency. For instance, omega-3 PL either in the form of krill oil (Batetta et al.
2009) or isolated from fish meal (Rossmeisl et al. 2012) reduced hepatic steatosis and the levels of endocannabinoids 2-AG and AEA in abdominal white adipose tissue (WAT) more efficiently than fish oils. However, although the superior effects of omega-3 phospholipids have been linked primarily to improved DHA and/or EPA bioavailability (see above), it is still unclear whether there are also other mechanisms involved.

Reflecting all the differences in bioavailability of omega-3 (see above), it is becoming apparent that omega- 3 index represents the best biomarker of omega- 3 status and indicator of the biological effects of these lipids, especially in lowering the risk of CVD (Harris 2008, Schuchardt and Hahn 2013; and see below). Variability of omega-3 index in erythrocytes, where EPA and DHA are contained in membrane phospholipids, is lower as compared with omega-3 index in plasma phospholipids (contained in lipoproteins) or total plasma lipids, while especially total plasma lipid omega-3 index shows the biggest differences $(\sim 11 \%)$ between fasted and fed state (Harris and Thomas 2010). This difference is only $\sim 1 \%$ and $\sim 5 \%$ in the case of omega- 3 index in erythrocytes and plasma phospholipids, respectively (Harris and Thomas 2010). Nevertheless, even omega-3 index in fasted plasma phospholipids could serve as an excellent biomarker of omega-3 status while predicting the risk of CVD (Mozaffarian et al. 2013; and below). A large prospective study on $\sim 2,700$ adult humans demonstrated a non-linear relationship between the content of omega-3 in the diet and in plasma phospholipids, with a sharp increase in the plasma omega-3 levels up to $0.5 \mathrm{~g}$ EPA+DHA daily dietary intake, and then smaller increases in the systemic levels thereafter (Mozaffarian et al. 2013). Our results in mice, also consistent with findings in humans, indicated saturable incorporation of DHA into plasma lipids, while a linear relationship between dietary and plasma EPA levels was found (Rossmeisl et al. 2012). Furthermore, our study indicated differences in the dose-dependent accumulation of EPA and DHA in various tissues in mice (Kopecky et al. 2009).

Concerning diverse biological effects of omega-3, primarily their whole-body anti-inflammatory action should be considered, which is important with respect to low-grade inflammation associated with obesity and metabolic syndrome, and which is also tightly linked with the metabolic effects of omega-3 in the liver, adipose tissue and muscle, i.e. tissues contributing the most to the underlying pathophysiology 
of IR and T2D. These mechanisms are being studied mostly in laboratory animals (see Fig. 1), while the extrapolation to humans is not straightforward.

\section{Effects of omega-3 in the liver}

Major mechanisms associated with the effects of omega-3 in the liver include (see also Fig. 1): (a) activation of PPAR $\alpha$, resulting in the increase of FA oxidation in both peroxisomes and to a lesser extent in mitochondria; (b) decrease of SREBP-1 gene expression, leading to the inhibition of lipogenic genes expression and lower formation of FA, TAG, and VLDL (Lombardo and Chicco 2006); (c) activation of AMPK in liver (Suchankova et al. 2005), probably through an adiponectin-mediated mechanism (Jelenik et al. 2010); and (d) higher production of anti-inflammatory omega-3derived lipid mediators (resolvins E1 and D1 and protectin D1) that protect hepatocytes from oxidative stress and DNA damage during necroinflammatory liver injury (Gonzalez-Periz et al. 2009, Rius et al. 2012).

In rodents, activation of PPAR $\alpha$ stimulates formation of peroxisomes much more than in humans (Delarue et al. 2004), reflecting the major differences in the PPAR $\alpha$ signaling between the two species (Rakhshandehroo et al. 2009). Induction of peroxisomal rather than mitochondrial $\beta$-oxidation was shown to mediate the anti-obesity effect of omega- 3 in rodents (Fiamoncini et al. 2013), which is consistent with a very weak or non-existent anti-obesity effect of omega-3 in humans (Mori et al. 1999, Skurnick-Minot et al. 2004, Kunesova et al. 2006; and see also Table 2). Stimulation of liver AMPK (see above) may augment metabolic effects of omega-3 based on the modulation of the activity of transcription factors PPAR $\alpha$ and SREBP-1. As a result of all these changes, liver TAG content decreases and the sensitivity of hepatocytes to insulin increases. At the whole organism level, the metabolic effects of omega-3 in the liver contribute to a decreased VLDL-TAG secretion (Kuda et al. 2009). Reduced plasma levels of TAG is the most prominent effect of a dietary intake of EPA and DHA in humans (Balk et al. 2004). However, this could be also a result of different mechanisms, such as modulation of postprandial lipid metabolism.

\section{Effects of omega-3 in adipose tissue}

Omega- 3 and the related oxylipins modulate gene expression through a variety of transcription factors and their effects are tissue-specific. In WAT, an important target is represented by peroxisome proliferator-activated receptor $\gamma(\operatorname{PPAR} \gamma)$. This is a nuclear receptor acting as a ligand-dependent transcription factor. It binds not only lipid molecules (above), but also TZD (Kintscher and Law 2005). After binding the ligands, PPAR $\gamma$ stimulates expression of genes engaged in differentiation of fat cells, namely genes encoding FA transporters and lipogenic genes. In fat cells, also other members of the PPAR family could be activated by the above ligands, namely $\operatorname{PPAR} \alpha$ and PPAR $\delta$, resulting in the stimulation of FA oxidation in mitochondria and peroxisomes (Luquet et al. 2005, Madsen et al. 2005, Hensler et al. 2011). As we have shown in mice, omega-3 stimulate formation of mitochondria in fat cells (Flachs et al. 2005) and specifically in epididymal WAT in the abdomen (but not in subcutaneous fat) activate the expression of the gene for carnitin-palmitoyl-transferase 1 (Flachs et al. 2005), that stimulates the entry of FA into mitochondria; see Figure 1. In abdominal WAT, omega-3 also induced mitochondrial $\beta$-oxidation measured ex vivo either in tissue fragments or in isolated adipocytes (Flachs et al. 2005, 2011). An increase of FA oxidation in fat cells may contribute to anti-obesity effects of EPA and DHA, and also to the hypolipidemic effects of these molecules. The protective action of omega-3 against obesity in mice seems to be stronger in case of DHA than EPA and it results in part from the inhibition of fat cell proliferation (Ruzickova et al. 2004, Hensler et al. 2011). The metabolic component of the anti-obesity effect of omega-3, especially in the combination treatment with calorie restriction, reflects marked stimulation of lipid catabolism in WAT which can be explained by the activation of a futile substrate cycle based on lipolysis of intracellular TAG and FA re-esterification (TAG/FA cycle) (Flachs et al. 2013, Janovska et al. 2013). Importantly, these changes are linked to a suppression of low-grade inflammation in this tissue (Flachs et al. 2011). Both, the metabolic and anti-inflammatory effect of omega-3 in WAT largely depends on the formation of their active metabolites (Flachs et al. 2011, 2013) and the normalization of the tonus of the endocannabinoid system (Rossmeisl et al. 2012), and are probably modulated by AMPK (Kopecky et al. 2009). Furthermore, our results demonstrate that the anti-obesity effect of omega- 3 is independent on uncoupling protein 1-induced thermogenesis (Flachs et al. 2013, Janovska et al. 2013; see Fig. 1). 


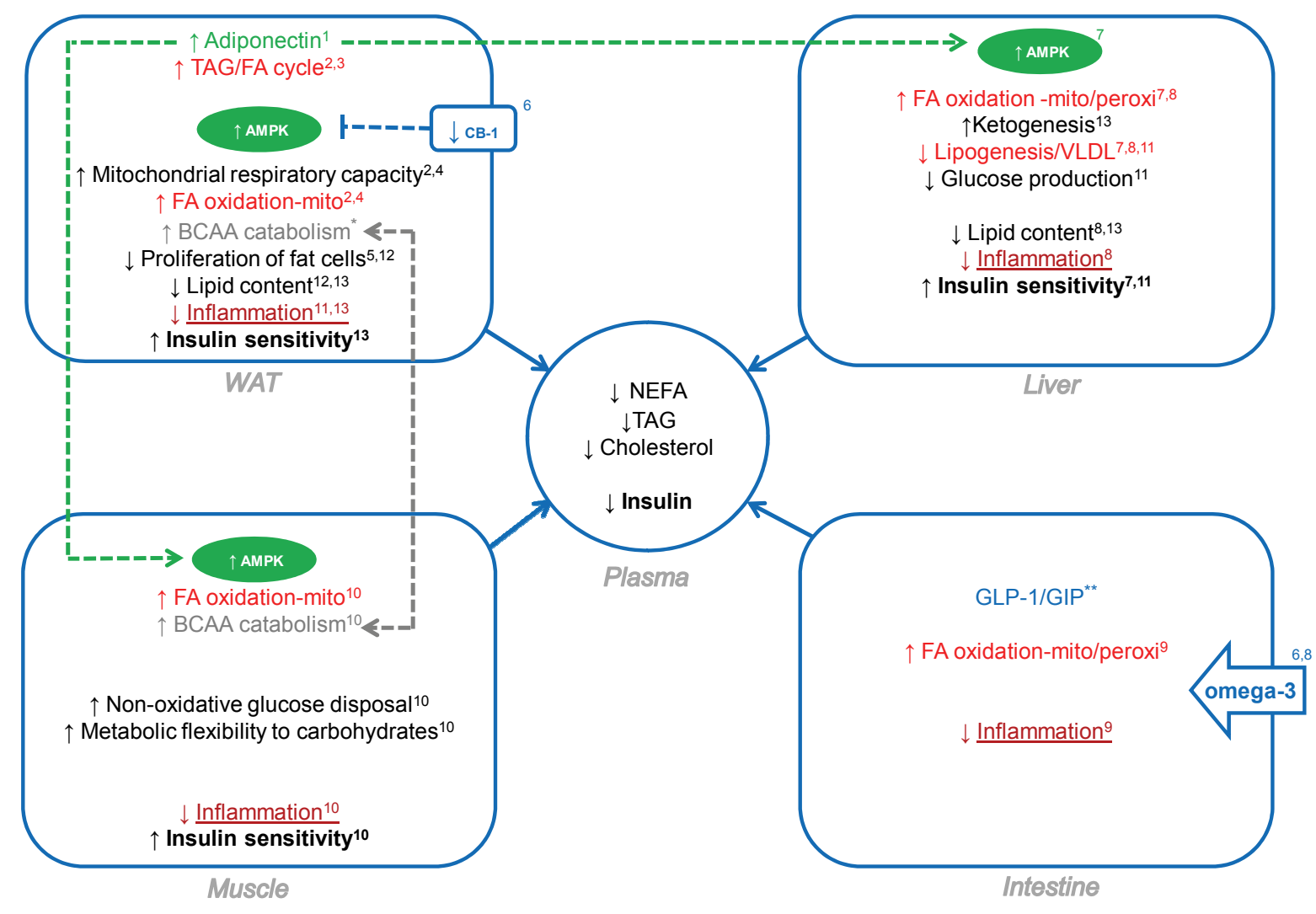

Fig. 1. Tissue effects of omega-3 as revealed by studies on dietary obese mice. Proposed scheme of modulation of metabolic fluxes in WAT, liver, skeletal muscle and intestine is based mostly on our studies on mice fed an obesogenic corn-oil based HF diet (15, 59, and $26 \%$ calories as protein, fat and carbohydrate, respectively) supplemented or not with omega-3 concentrate (replacement of 5 to $44 \%$ of dietary lipids). The bioavailability and tissue accumulation of dietary DHA and especially of EPA were higher when omega-3 were supplemented as phospholipids instead of TAG. Appropriate studies are indicated by numbers: 1 - Flachs et al. 2006; 2 - Flachs et al. 2013; 3 - Janovska et al. 2012; 4 - Flachs et al. 2005; 5 - Ruzickova et al. 2004; 6 - Rossmeisl et al. 2012; 7 - Jelenik et al. 2010; 8 - Rossmeisl et al. 2014; 9 - van Schothorst et al. 2009; 10 - Horakova et al. 2012; 11 - Kuda et al. 2007; 12 - Hensler et al. 2011; 13 - Flachs et al. 2011; * - our unpublished results; ** - intracolonic administration of omega-3 in mice resulted in enhanced GLP-1 secretion, substantial insulin release and subsequent reductions in glycemia (Morishita et al. 2008), our unpublished data suggest that omega-3 potentiate GLP-1 and insulin responses to a glucose load while normalizing abnormally elevated GIP levels observed in the HF diet-fed mice.; CB-1, cannabinoid receptors 1, decrease in the endocannabinoids tonus; mito/peroxi, mitochondrial/peroxisomal.

Also TZD stimulate formation of mitochondria in adipose tissue (Wilson-Fritch et al. 2004). However, in contrast to EPA and DHA, TZD also stimulate growth of adipose tissue. The growth of adipose tissue is associated with a formation of small adipocytes (Okuno et al. 1998). Because the small cells have a larger capacity for "trapping" FA as compared to large adipocytes, small adipocytes could serve as a "buffer" for lipids and in this way protect tissues against the lipotoxicity (Danforth 2000). The key role of WAT in glucose homeostasis is also supported by a finding of improved insulin sensitivity in mice with fat-specific over-expression of PPAR $\gamma$ (Sugii et al. 2009), which potentially involves changes in WAT distribution and fat cell size (see above), lowering of plasma non-esterified FA (NEFA) levels due to an activation of TAG/FA cycle in adipocytes (reviewed in Flachs et al. 2013), and stimulation of the FGF1-based mechanism (Jonker et al. 2012).

Omega-3, as well as TZD, modulate the secretion of adipokines from WAT. As shown in our laboratory (Flachs et al. 2006) and by others (Rossi et al. 2005, Neschen et al. 2006), EPA a DHA induce adiponectin in mice fed obesogenic diets, possibly via PPAR $\gamma$ acting directly upon the promoter of adiponectin gene (Iwaki et al. 2003). Moreover, preferential induction of adiponectin by the EPA/DHA concentrate in abdominal WAT was found (Flachs et al. 2006). While this induction of adiponectin by omega-3 was confirmed by some but not all human studies (Wu et al. 2013), it could contribute to the insulin-sensitizing effect of TZD. In contrast to adiponectin, plasma leptin levels were elevated dramatically in response to HF feeding, but 
neither these nor leptin gene expression were affected by dietary EPA/DHA, supporting the idea that circulating leptin correlates with adiposity and glucose metabolism in adipocytes (Takahashi and Ide 2000).

In the fat cells, omega-3 also affect the expression of GLUT4 gene (Ruzickova et al. 2004) and glucose transport into the cells. In rodents, both GLUT4 expression and glucose transport are inhibited by a HF diet in parallel with the induction of IR, while admixing EPA and DHA to the diet has protective effects (Lombardo and Chicco 2006).

In addition, high anaplerosis in WAT mitochondria in obesity may result in insufficient oxidation of metabolites arising from degradation of branched-chain amino acids (BCAA), supporting further the development of systemic insulin resistance (Newgard et al. 2009, Adams 2011). TZD support BCAA catabolism in WAT (Hsiao et al. 2011), which may contribute significantly to the insulin-sensitizing effect of TZD in obesity (Newgard 2012). Our unpublished results suggest that also omega-3 could increase BCAA catabolism in WAT of mice (Fig. 1).

\section{Effects of omega-3 in skeletal muscle}

Preventive effects of EPA and DHA on the development of IR in muscles of rodents fed a HF diet correlate well with a decrease of muscle TAG content (Storlien et al. 1991). This most likely reflects the hypolipidemic effect of EPA and DHA, which results from a decrease in lipogenesis and increase of lipid oxidation in both liver and adipose tissue (see above). Adiponectin induced by EPA and DHA (and also by TZD) may stimulate AMPK in the muscle. In turn, AMPK augments oxidation of FA in myocytes and the influx of glucose into these cells (Yamauchi et al. 2002).

Omega-3 could affect muscle insulin sensitivity also via PPAR $\gamma$-mediated mechanism in muscle cells. This is in agreement with a presence of IR in mice harbouring muscle-specific disruption of PPAR $\gamma$ (Hevener et al. 2003, Kintscher and Law 2005). Direct effects of omega-3 on tissue metabolism depend in large on the accumulation of these FA in phospholipids of cell membranes and modulation of oxylipin metabolism (Storlien et al. 1991; see above). Interestingly, the content of DHA in membrane phospholipids in human muscle also increased following a 4-week exercise (Helge et al. 2001).

Our results obtained in dietary obese mice indicate that the combined use of omega-3 and TZD exert synergistic beneficial effects in the prevention as well as reversal of IR (Kuda et al. 2009), while additively preserving metabolic flexibility to carbohydrates (Horakova et al. 2012; see Fig. 1). These effects reflected an improvement in skeletal muscle insulin sensitivity by the combined treatment, expressed as synergistic induction of glycogen synthesis at the basal and insulin stimulated conditions (Kuda et al. 2009). Moreover, metabolomic and gene expression analyses in skeletal muscle suggested complementary effects of the single interventions, with TZD augmenting insulin sensitivity by the modulation of BCAA metabolism, especially when combined with omega-3, and omega-3 supporting specifically mitochondrial oxidation of fatty acids. These metabolic effects were associated with the activation of a switch between glycolytic and oxidative muscle fibres and inhibition of low-grade tissue inflammation (Horakova et al. 2012).

\section{The effect of omega-3 on insulin sensitivity and obesity-associated disorders}

In the following text, animal and human studies will be commented separately, reflecting the fact, that the animal studies, while indispensable for understanding the mechanisms, have a clear limitation as far as the characterization of health benefits of omega-3 is concerned.

\section{Effects of omega-3 on insulin sensitivity in animal models}

Most studies carried out in animal models, mostly rodent species have focused on the development of IR, but relatively few have examined the effectiveness of these compounds in reversal of IR. Both prevention and reversal of IR have been studied in animals fed by the diet with a high content of either fat or carbohydrate, particularly sucrose or fructose (see below).

\section{Prevention of IR by omega-3 in dietary obese rodents}

HF diets induce accumulation of body fat and obesity, which is associated with alterations in insulin sensitivity, glucose intolerance, hyperinsulinemia and changes in lipid metabolism. In case of the effect of omega-3 on IR, it is the work of Storlien and colleagues (1987, 1991) that laid down the foundations of our current knowledge. These authors have shown that the replacement of only $6 \% \mathrm{LA}$ in the HF diet (in which plant oil was the only source of lipids and formed $59 \%$ 
of energy) for EPA and DHA protected the animals against the development of IR and limited the accumulation of adipose tissue. These effects are also reflected in lower plasma concentrations of TAG, NEFA and insulin (Lombardo and Chicco 2006).

Our studies on dietary obese mice fed a corn oil-based HF diet (Ruzickova et al. 2004, Flachs et al. 2006, Rossmeisl et al. 2012, Janovska et al. 2013) indicate that replacement of 5 to $44 \%$ of dietary lipids by omega-3 in the form of either TAG or phospholipid can protect against the development of dyslipidemia, impaired glucose homeostasis and IR (see above). Furthermore, a series of our studies on the combined use of omega-3 with TZD (Kuda et al. 2009, Kus et al. 2011, Horakova et al. 2012, Rossmeisl et al. 2014) or calorie restriction (Flachs et al. 2011) clearly demonstrated that omega-3 markedly potentiate the beneficial effects of the combination treatments on insulin sensitivity, glucose tolerance, metabolic flexibility to carbohydrates, lipid metabolism and obesity (see above).

Concerning the link between abdominal fat accumulation and metabolic syndrome, it is important to stress that in HF diet-fed animals, omega-3 preferentially limit accumulation of gonadal and visceral WAT. This differential effect on fat depots is associated with changes in the expression of metabolic genes engaged especially in lipid metabolism and glucose uptake in adipocytes (Hun et al. 1999, Azain 2004, Ruzickova et al. 2004).

Rats fed high-carbohydrate (rich in sucrose or fructose) diets (HC) for a short period (3-6 weeks) develop hypertriglyceridemia, hyperinsulinemia, increased plasma NEFA levels and IR in peripheral tissues (Klimes et al. 1993). However, HC diet does not lead to an enhanced accumulation of fat despite the fact that other features of the metabolic syndrome are present. When omega-3 concentrate replaces the usual lipid constituent (oil) present in the $\mathrm{HC}$ diet, it prevents the onset of dyslipidemia and impaired glucose homeostasis. WAT, and in particular its insulin sensitivity, might play a crucial role in the omega-3's effect (Huang et al. 1997, Peyron-Caso et al. 2002). Increased dietary intake of fish oil restored the activity of insulin receptor tyrosine kinase towards control values (Fickova et al. 1994).

Besides many studies on laboratory rodents, there are only few investigations in other animal models. One study (Behme 1996) has shown that insulin sensitivity in miniature pigs is enhanced by omega-3 provided even in the context of low-fat diet feeding, while omega-3 could also reduce abdominal fat deposition in birds (Newman et al. 2002).

Thus, even partial substitution of dietary lipids with EPA/DHA in either HC or HF diet is associated with a number of effects that can help to prevent the development of IR. Although the mechanism responsible for beneficial effects of omega- 3 on insulin sensitivity in above mentioned animal models is not entirely clear, the common feature associated with omega-3 treatment primarily involves improved hepatic insulin sensitivity (Storlien et al. 1987, Neschen et al. 2007, Kuda et al. 2009, Jelenik et al. 2010) associated with reduced hepatic diacylglycerol accumulation (Neschen et al. 2007, Jelenik et al. 2010), reduced TAG deposition in various insulinresponsive tissues (Flachs et al. 2011, Rossmeisl et al. 2012) and low-grade inflammation of WAT (Kuda et al. 2009, Flachs et al. 2011, Rossmeisl et al. 2012).

\section{Reversal of IR by omega-3 in animals}

Some studies have shown acute effects of EPA/DHA administration in obese rodents (Shimura et al. 1997, Holness et al. 2004). Thus, acute (24-h) replacement of $7 \%$ of dietary FA reversed insulin hypersecretion in vivo by rats fed HF diet and reverses the effects of HF feeding to enhance insulin secretion by perfused islets (Holness et al. 2004).

Relatively few studies have examined possible reversal of already established IR and obesity in response to omega-3, i.e. the metabolic condition relevant to T2D. In some studies, a model of IR induced by $\mathrm{HC}$ diet in the rat was used. Administration of omega-3 as fish oil normalized the levels of TAG, NEFA and glucose in plasma, TAG content and glycogen synthesis in the skeletal muscle, and glucose tolerance and whole-body insulin sensitivity (Lombardo et al. 1996, Pighin et al. 2003, Rossi et al. 2005). Furthermore, omega-3 completely normalized both fat storage and the pyruvate dehydrogenases activity within the $\beta$-cells as well as the insulin secretion patterns (Pighin et al. 2003). In contrast, another study with a similar design did not show any effect of omega-3 on established IR in rats (Podolin et al. 1998). We were able to demonstrate some of the beneficial effects of omega- 3 administered as either TAG (Kuda et al. 2009, Rossmeisl et al. 2009, 2012) or phospholipid (Rossmeisl et al. 2012) on established obesity, glucose intolerance and dyslipidemia using the model of HF diet-fed C57BL/6J mice.

The results obtained using both $\mathrm{HC}$ diet-fed (Rossi et al. 2005) and HF diet-fed (Flachs et al. 2006, Jilkova et al. 2013; and see above) animals suggest that 
modulation of secretion of adipokines by dietary omega-3 might play an essential role in the normalization of insulin sensitivity and adiposity in insulin-resistant models with diet-induced obesity.

Several studies (Linn et al. 1989, Churnratanakul et al. 1990, Giron et al. 1999, OvideBordeaux and Grynberg 2004) have also documented improvement of hyperglycemia in an experimental rat model of streptozotocin-induced type 1 diabetes, i.e. diabetes resulting primarily from decreased secretion of insulin.

Effects of omega-3 in rodent models of spontaneous diabetes mellitus or $I R$

Single administration of DHA decreased in a dose-dependent manner both plasma glucose and NEFA levels in diabetic KK-A $\mathrm{A}^{\mathrm{y}}$ mice (Shimura et al. 1997). Repeated administration of DHA reduced blood glucose, TAG and NEFA levels, decreased blood glucose during insulin tolerance test and reduced adiposity in $\mathrm{KK}-\mathrm{A}^{\mathrm{y}}$ mice (Shimura et al. 1997, Hun et al. 1999). In OLETF rats, an animal model of T2D, EPA supplementation lowered plasma TAG levels and abdominal fat accumulation and improved IR (Minami et al. 2002). In male WBN/Kob rats, a model of spontaneous diabetes mellitus, oral EPA treatment suppressed significantly and dose-dependently the incidence of diabetes (Nobukata et al. 2000). Dietary omega-3 have beneficial effects on both hypertension and glucose intolerance in spontaneously hypertensive (SHR) rats (Ajiro et al. 2000). In Goto-Kakizaki rat, an animal model of T2D, EPA improved glucose tolerance by directly increasing hepatic insulin sensitivity (Matsuura et al. 2004). In genetically obese $o b / o b$ mice, fish oil-containing diet reduced the body weight gain and increased glucosestimulated insulin secretion (GSIS), but also increased intercurrent mortality (Steerenberg et al. 2002).

\section{Modulation of the incretin system by omega-3}

$\mathrm{T} 2 \mathrm{D}$ is characterized by the presence of IR and $\beta$-cell dysfunction. While the loss of $\beta$-cell function is pivotal for the T2D development, there are also defects in other endocrine systems that regulate glucose homeostasis (e.g. glucagon, incretins), which contribute to abnormal GSIS and other metabolic abnormalities. For instance, incretin hormones glucagon-like peptide-1 (GLP-1) and glucose-dependent insulinotropic polypeptide (GIP), apart from other functions (for review see Mudaliar and Henry 2012), augment GSIS after they are released from the gut in response to glucose and other nutrients absorption (i.e. incretin effect). This effect seems to be blunted in T2D subjects (Nauck et al. 1986), likely due to an impaired response to GIP and possibly also to GLP-1 (Hojberg et al. 2009), or in some cases due to a reduced GLP-1 secretion (Nauck 2011). Thus, dietary omega-3 could exert some of their beneficial effects on IR and glucose homeostasis through the modulation of incretin hormones. In this regard, intracolonic administration (but not into other intestinal segments) of DHA and EPA in mice resulted in enhanced GLP-1 secretion, substantial insulin release and subsequent reductions in glycemia (Morishita et al. 2008). We have previously shown in mice that dietary DHA/EPA at the dose of $30 \mathrm{~g} / \mathrm{kg}$ diet ameliorated wholebody IR induced by chronic HF feeding, mainly due to the modulation of hepatic insulin sensitivity (Kuda et al. 2009, Jelenik et al. 2010). Our unpublished data suggest that this level of DHA/EPA supplementation potentiates GLP-1 and insulin responses to a glucose load while normalizing abnormally elevated GIP levels observed in the control high-fat diet-fed mice. However, it is unclear whether a similar beneficial effect of omega-3 supplementation on the incretin system could be recapitulated in human subjects with IR and/or T2D.

\section{Effects of omega-3 on insulin sensitivity and glucose homeostasis in humans}

Most animal experiments document beneficial effects of omega-3 on insulin sensitivity and glucose metabolism even under conditions of established obesity and IR (see above). However, the situation in humans is more complicated, suggesting that omega-3's effects may depend on disease progression, age of subjects and other variables. Therefore, for the purpose of this review, the effects of omega-3 on glucose homeostasis and related metabolic features will be examined separately within three major categories of subjects: healthy individuals, subjects with metabolic syndrome, and patients with T2D. Moreover, the effects in CVD patients will be also described.

\section{Effects of omega-3 in healthy individuals}

Cross-sectional studies documented that Greenlandic Inuits with a high dietary intake of marine fish had a lower incidence of atherosclerosis, type 1 diabetes and T2D (reviewed in Dyerberg 1986, Bjerregaard et al. 2000), while human population from fishing areas in Japan exhibited a relatively low incidence 
of CVD, in association with lower plasma levels of cholesterol, LDL cholesterol (LDL-C), saturated FA, and omega-6 without changes in blood glucose (Nakamura et al. 2003). However, many of the subsequent observational studies gave inconsistent results with respect to the association between omega-3 intake and the incidence of either CVD or T2D (reviewed in Zheng et al. 2012).

In their seminal prospective cohort studies, Feskens et al. have shown that increased intake of marine fish could lower a relative risk of IGT in elderly individuals by $60 \%$ (Feskens et al. 1991) and correlated negatively with glycemia 2 hours after glucose load (Feskens et al. 1995). Also some of the more recent prospective cohort studies observed a negative association between fish intake, namely of fatty fish (Patel et al. 2012, Zhang et al. 2013), and the risk of T2D, while some studies did show the opposite (Kaushik et al. 2009, Djousse et al. 2011b). A meta-analysis of the results of prospective-cohort studies performed by the group of Mozaffarian could not prove a significant association of either EPA+DHA or fish/seafood intake with the risk of $\mathrm{T} 2 \mathrm{D}$ ( $\mathrm{Wu}$ et al. 2012b). Importantly, however, in a prospective cohort study performed by the Mozaffarian's group on generally healthy older adults in the US, in which circulating omega-3 levels (namely omega-3 index in plasma phospholipids) rather than dietary intake of omega-3 (assessed using dietary questionnaires in the other studies) were evaluated at the baseline year, circulating omega-3 were associated with lower CVD mortality (Cardiovascular Health Study; see Mozaffarian et al. 2013), lower risk of atrial fibrillation (Wu et al. 2012a), and possibly also with a lower risk of T2D (Djousse et al. 2011a). These results are in agreement with the findings of another large prospective cohort study concluded in 2013, which showed a longterm lower risk of T2D in older men with high plasma EPA+DHA levels (Virtanen et al. 2014), but they are not supported by all the studies with a similar design (reviewed in Djousse et al. 2011a).

Randomized clinical trials (RCTs) with omega-3 in healthy individuals consistently document lipidlowering effects with a decrease in plasma TAG by 20-30\% (Bhathena et al. 1991, Williams et al. 1992, Marckmann et al. 1997, Balk et al. 2004, Brady et al. 2004, Faeh et al. 2005). Some (Lahoz et al. 1999) but not all (Gustafsson et al. 1998) studies also reported a decrease in blood pressure. With respect of glycemic control, studies report either no change (Marckmann et al. 1997, Bordin et al. 1998, Lahoz et al. 1999) or impairment (Bhathena et al. 1991, Delarue et al. 1996, Minihane et al. 2005) of glycemic control after omega-3 administration. Some studies report lowering (Delarue et al. 1996, Gustafsson et al. 1998) or no change (Marckmann et al. 1997, Bordin et al. 1998, Lahoz et al. 1999, Fontani et al. 2005) of plasma insulin in response to omega-3.

The changes in glucose metabolism suggest that: (a) omega-3 might interfere with insulin secretion, which leads to a decrease in circulating insulin levels and a concomitant rise in blood glucose; and (b) the administration of omega-3 likely induces a switch in substrate metabolism, namely an increase in whole-body fat oxidation and a decrease in carbohydrate oxidation (Couet et al. 1997, Delarue et al. 2003). Thus, a 3-weekintervention with omega-3 in young subjects resulted in increased glycemia after a carbohydrate load, decrease in insulinemia, depression in carbohydrate oxidation, increase in lipid oxidation, while non-oxidative glucose disposal was elevated (Delarue et al. 1996). In a similar study, omega-3 administration resulted in reduced stimulation of glucose disposal and hepatic glucose production during exercise, while stimulating lipid oxidation (Delarue et al. 2003). These results suggest an inhibition of hepatic glucose production by a feedback mechanism (Delarue et al. 2003). In fact, the increase in non-oxidative glucose disposal documents increased insulin sensitivity of skeletal muscle, and suggests high metabolic flexibility to carbohydrates.

Thus, while the beneficial effects of omega- 3 on blood lipids, especially TAG, in healthy individuals are evident, the same cannot be said about their effects on insulin sensitivity and glycemic control. A majority of association studies analysing dietary intake or plasma levels of omega-3, and metabolic parameters in various populations confirm that, in the long term, omega- 3 have a beneficial effect. On the other hand, studies analysing the effect of acute administration of omega-3 on glycemic control in healthy individuals gave ambivalent results and the cause for these diverse effects is not entirely clear (see below).

\section{Effects of omega-3 in subject with metabolic syndrome}

Obesity and associated disorders included in metabolic syndrome, namely dyslipidemia, IGT and hypertension, predispose to both CVD and T2D. Regarding obesity itself, numerous clinical intervention studies were conducted showing either none or only 
marginal weight-reducing effects of omega-3 intake (reviewed in Lorente-Cebrian et al. 2013). It seems logical that the additive weight-reducing effect was often detected when omega-3 intake was combined either with physical exercise (Warner et al. 1989, Hill et al. 2007) or reduced calorie intake (Mori et al. 1999, Krebs et al. 2006, Kunesova et al. 2006, Thorsdottir et al. 2007), also in accordance with our study in mice showing a strong prevention of dietary obesity in response to calorie restriction combined with omega-3 intake (Flachs et al. 2011; and see above). Interestingly, several association studies in humans also document a negative correlation between omega-3 content in WAT (Pietilainen et al. 2007) or plasma lipids (Micallef et al. 2009) and obesity.

While hypertriglyceridemia supports the development of atherosclerosis and CVD, lipid-lowering effects of omega-3 consistently observed in metabolic syndrome patients (reviewed in Jeppesen et al. 2013) may represent one of the key factors underlying the beneficial role of omega-3 in both primary (see above) and possibly also secondary (see below) prevention of CVD. A metaanalysis of studies in patients with metabolic syndrome or T2D (MacLean et al. 2004), published in 2004, has shown, that although omega-3 significantly lowered plasma TAG compared to placebo, omega-3 affected neither total cholesterol levels, HDL-cholesterol, LDL-C, $\mathrm{HbA1c}$, nor fasting glycemia.

Profound changes in glucose homeostasis represented by IGT and IR, which could eventually lead to $\mathrm{T} 2 \mathrm{D}$, represent the characteristic feature of metabolic syndrome. Several intervention trials performed mostly in obese children (Lopez-Alarcon et al. 2011, Dangardt et al. 2012, Juarez-Lopez et al. 2013) or in young overweight or obese individuals (without T2D) demonstrated an amelioration of IGT and IR (Ramel et al. 2008), independently from changes in body weight (Ramel et al. 2008, Dangardt et al. 2012). Similar studies in adult patients showed mixed results (reviewed in Lorente-Cebrian et al. 2013). A study, in which the effect of fish oil was studied in patients with IGT using hyperinsulinemic clamp, documented beneficial effects of omega-3 on insulin sensitivity evaluated at the lower but not higher insulin concentrations (Fasching et al. 1991).

The beneficial effects on metabolic syndrome features are associated, and could be explained in part, by the anti-inflammatory effects of omega-3 (see above). In human subjects with metabolic syndrome, the antiinflammatory influence of omega-3 is well documented both at the systemic level (Calder and Yaqoob 2010,
Itariu et al. 2012, 2013) as well as in adipose tissue (Itariu et al. 2012, Neuhofer et al. 2013).

The above data indicate that omega-3 could ameliorate various features of metabolic syndrome including the impairment of glucose homeostasis in prediabetic subjects, which could be masked or augmented by many variables. In this respect, it is no surprise that cross-sectional studies on the effects of omega-3 on metabolic syndrome as a whole, while neglecting important variables and possible effects on specific features of metabolic syndrome, gave negative results (e.g. Lai et al. 2013).

\section{Effects of omega-3 in patients with T2D}

Motivated by the initial discovery regarding the prevention of IR by omega-3 supplementation in rats fed HF diet (Storlien et al. 1987, 1991) and by the results of the early epidemiological studies showing a lower risk of T2D and CVD in some populations (see above), numerous intervention trials focusing on the effect of omega- 3 on glucose homeostasis in diabetic patients have been conducted. The initial results obtained in small patient cohorts in the late 80's and early 90's (using less concentrated omega-3 products or natural fish oils) were not encouraging, since they showed either no (Kasim et al. 1988) or detrimental (Glauber et al. 1988, Borkman et al. 1989, Hendra et al. 1990, Vessby and Boberg 1990) effects on glucose homeostasis. Fasting blood glucose was elevated (Glauber et al. 1988, Borkman et al. 1989, Hendra et al. 1990, Vessby and Boberg 1990) and hepatic glucose production increased (Glauber et al. 1988), while glucose disposal rate and glucose tolerance were either decreased (Vessby and Boberg 1990) or unchanged (Glauber et al. 1988). Although fasting insulin levels were unchanged, glucose-stimulated insulin levels were lowered by omega-3 supplementation (Glauber et al. 1988).

As reviewed in detail previously (Mostad et al. 2006), subsequent RCTs in patients with T2D could not find better insulin sensitivity after omega-3 supplementation, while some of the studies even revealed decreased insulin secretion in omega-3-treated subjects. Nevertheless, most of the subsequent studies showed no change in glycemic control (i.e. based on fasting blood glucose or HbA1c levels) after omega-3 supplementation (Fasching et al. 1991, Pelikanova et al. 1993, Axelrod et al. 1994, McGrath et al. 1996, McManus et al. 1996, Goh et al. 1997, Sirtori et al. 1997, Kesavulu et al. 2002, Bosch et al. 2012), while proving hypotriglyceridemic 
effects of omega-3. A very recent RCT in T2D patients revealed a positive effect of purified EPA-based supplement on glucose homeostasis (Sarbolouki et al. 2013).

A deterioration of insulin sensitivity in obesity could reflect several different mechanisms, including glucotoxicity and lipotoxicity, while it is marked by an impaired metabolic flexibility (see the section Key mechanisms underlying deterioration of insulin sensitivity above). Various animal studies document increased lipid catabolism by omega-3, which could be involved in counteracting lipotoxic damage of insulin signaling (see above). In contrast to a large number of studies examining the effects of omega- 3 on glucose homeostasis and insulin sensitivity in T2D patients, studies focused on the effects of omega-3 on metabolic flexibility in T2D patients, typically assessed using indirect calorimetry, are scarce. In one RCT on T2D patients (Mostad et al. 2006), indirect calorimetry in fasted state demonstrated temporarily increased glucose utilization after 1 week of omega-3 treatment, after which (after 9 weeks of treatment) it was decreased with a concomitant increase in lipid utilization. Glucose utilization evaluated during the indirect calorimetry by using hyperinsulinemic euglycemic clamp, a conventional measure of insulin sensitivity, was also decreased. Although indirect calorimetry was also performed at the end of the clamp study, the potential effect of omega-3 on metabolic flexibility is difficult to assess from the available data. In another RCT performed by the same group, in which the acute effects of omega-3 administered as lipid infusion were tested in patients with T2D, no change in insulin sensitivity was observed using hyperinsulinemic euglycemic clamp, while indirect calorimetry suggested a marginal improvement of metabolic flexibility (Mostad et al. 2009).

It is to be inferred that the interpretation of the results of the conventional measurements regarding the effects of omega-3 on glucose homeostasis and insulin sensitivity are complicated by the time-dependent changes in the capacity to oxidize carbohydrate and lipid fuels in response to omega-3. Nevertheless, the available data suggest that omega-3 have a neutral/marginal effect on glycemic control in diabetic patients, while exerting beneficial hypolipidemic effects.

\section{Effects of omega-3 in patients with CVD}

Diabetes imposes the risk of CVD morbidity and mortality, which in turn represent the major adverse events in T2D patients (Seshasai et al. 2011). Reflecting the positive results of several cross-sectional and prospective cohort studies with respect to prevention of CVD and T2D by omega-3 (see above), several major RCTs were focused on the effect of omega- 3 in subjects with a history of myocardial infarction or other CVD risk factors. In spite of positive data coming from the older RCTs showing beneficial effects in the secondary prevention of CVD (especially the influential GISSI trial; Marchioli 1999), in the majority of the recent RCTs of a similar design (Kromhout et al. 2010, Rauch et al. 2010, Roncaglioni et al. 2013) omega-3 did not significantly reduce CVD-related morbidity and mortality. This was also true for the ORIGIN trial performed on 12,536 people (mean age of 63.5 years and median follow-up of 6.2 years) with IFG, IGT, or T2D, who were also at risk of CVD events (Bosch et al. 2012, Gerstein et al. 2012). In this trial with 2-by-2 factorial design, in which the effects of omega-3 (1 g EPA+DHA ethyl ester daily) and insulin glargine were tested, neither omega-3 nor glargine reduced the risk of CVD events, but omega-3 exerted a hypotriglyceridemic effect (Bosch et al. 2012) while glargine reduced new-onset diabetes, increased hypoglycemia and increased weight (Gerstein et al. 2012).

The reasons for the contrasting results regarding omega-3's effects on CVD events observed in the older versus more recent RCTs are not clear (see below); that unknown variables could modulate the effects of omega-3 is also documented by the contrasting results of two recent meta-analyses (Kwak et al. 2012, Casula et al. 2013). Interestingly, secondary analysis of the results of one of the RCTs performed in patients with previous myocardial infarction, showing negative results with respect to the secondary prevention of CVD by omega-3 in the whole patients' cohort (Kromhout et al. 2010), suggested protective effects in the subgroup of patients with T2D (Kromhout et al. 2011). Also in the JELIS trial performed on 18,645 hypercholesterolemic patients in Japan (i.e. the population with a high fish intake), encompassing either normoglycemic patients or patients with IGT or T2D, the treatment with EPA resulted in a reduced incidence of CVD with stronger effects in the prediabetic than in diabetic patients (Oikawa et al. 2009). Unfortunately, whether omega-3 could reduce new-onset diabetes was not evaluated neither the ORIGIN nor in the JELIS trial.

The lack of health benefits of omega-3 administration in some of the RCTs was interpreted in 
a way that the effect of omega-3 could be too weak to be manifested against the background of intensive modern preventive therapy. For instance, it has been suggested that some effects of statin drugs could counteract the CVD health benefits of omega-3 (de Lorgeril et al. 2013). Although attractive, this hypothesis does not seem to be the main explanation, reflecting also the observed additional benefits of the combination therapy using omega-3 and statins on dyslipidemia in T2D patients (de Lorgeril et al. 2013). A recent retrospective matchedcontrol study on patients after myocardial infarction with or without T2D documented that omega-3 supplementation was associated with a $22 \%$ reduction of all-cause mortality, independent of other CVD-risk modifying treatments (Poole et al. 2013); in this study, 2,466 eligible subjects were exposed to omega-3 and each of them was matched to 4 other patients that had been without omega-3. Importantly, this ,real-world evaluation of clinical practice" complements RCTs by demonstrating that a treatment with licenced omega-3 was associated with reduced all-cause mortality only when initiated within 90 days and preferentially within 14 days after the myocardial infarction (Poole et al. 2013), i.e. under the conditions met by only one of the recent RCTs (Rauch et al. 2010). However, as stated by the authors of this trial, the data do not allow a final answer on the potential CVD-related benefits of omega-3, since the study was statistically underpowered (Rauch et al. 2010). None of the RCTs was designed to uncover potential interactions between omega-3 and glucoselowering drugs.

Thus, in spite of the tremendous efforts spent in the RCTs above, definitive conclusions regarding the effects of omega-3 in the secondary prevention of CVD, or in the development of new-onset diabetes in high-risk persons cannot be made.

\section{Conclusions}

While the results of both animal and human studies document beneficial effects of omega-3 with respect to prevention/normalization of hypertriglyceridemia and amelioration of systemic lowgrade inflammation as well as tissue inflammatory changes, which are accompanying obesity, the results are inconsistent regarding the effects of omega- 3 on glucose homeostasis and insulin sensitivity in animal models and in human subjects. While in the animal studies, namely in dietary obese mice, omega-3 are consistently shown to prevent IR and to reverse already established IR, the situation in human subjects is more complex.

Most of the cross-sectional studies in healthy populations, as well as intervention studies in people with metabolic syndrome, document that omega-3 could prevent development of T2D and ameliorate disorders of glucose homeostasis. Such conclusion is also supported by a prospective cohort study in generally healthy older adults, in which omega-3 levels in circulation rather than dietary omega-3 intake were evaluated. Results of the majority of RCTs performed in patients with T2D suggest that omega-3 have none or marginal effects on metabolic control, while effectively reducing hypertriglyceridemia in these patients. In spite of this beneficial hypolipidemic action of omega-3, the results of several recent RCTs mostly suggest no effect of omega-3 in secondary prevention of CVD, but confounding factors could be involved and thus no definitive conclusion could be made. Potential effects of omega-3 on a risk of new-onset diabetes in prediabetic subjects remain to be characterized.

Regarding the effects of omega- 3 on glucose homeostasis and insulin sensitivity, many factors may underlie the interspecies differences as well as the inconsistent outcomes of the human studies. Some mechanisms may differ among the species, namely those involving hepatic action of omega-3. While the animal studies are much easier with respect to elimination of many confounding effects (genetic background including the effects of various allelic forms of critical genes, diet composition, adherence to the treatment, age, environment, etc.), the human studies are inherently much more heterogeneous, reflecting not only the variables that are controlled for in the animal studies (see above), but also with respect to the interactions with other pharmaceuticals used for the treatment of patients. Factors modulating bioavailability of omega-3, like their lipid form and/or the presence of other nutrients, may be critical. It is conceivable that also in human subjects, the effects of omega-3 will be better established when the assessment of omega-3 index is taken into account. It will be also helpful to control for the effects of more critical variables in well focused studies and using combinations of appropriate phenotyping approaches for specific end points.

In spite of the negative results observed in many clinical studies, namely EPA and DHA have been shown to exert numerous beneficial effects on health and should be increasingly used in the prevention of T2D, CVD and 
other diseases that are frequently associated with obesity and inflammation. Current guidelines regarding omega-3 intake in general population should be followed. The use of omega-3 and changes in lifestyle in the therapy of major diseases including T2D should be further explored, namely with respect to their combination with pharmaceuticals.

\section{Conflict of Interest}

There is no conflict of interest.

\section{Acknowledgements}

Supported by the Ministry of Health of the Czech Republic (NT13763-4) and RVO: 67985823.

\section{Abbreviations}

AA, arachidonic acid (20:4n-6); ALA, $\alpha$-linolenic acid (18:3n-3); BCAA, branched-chain amino acids; CVD, cardiovascular disease; DHA, docosahexaenoic acid (22:6n-3); FA, fatty acids; HbA1c, glycated hemoglobin;
HC, high carbohydrate diet; HDL, high-density lipoprotein; HF, high-fat diet; EPA, eicosapentaenoic acid (20:5n-3); GIP, glucose-dependent insulinotropic polypeptide; GLP-1, glucagon-like peptide-1; GSIS, glucose-stimulated insulin secretion; IFG, impaired fasting glucose; IGT, impaired glucose tolerance; IR, insulin resistance; LA, linoleic acid (18:2n-6); LC-PUFA, long-chain polyunsaturated fatty acids; LDL, low-density lipoprotein; LDL-C, LDL cholesterol; NEFA, nonesterified fatty acids; $n-6 / n-3$, ratio between $n-6$ and $n-3$ polyunsaturated fatty acids in the diet; omega-3, longchain polyunsaturated fatty acids $n-3$ series; OGTT, oral glucose tolerance test; PPAR, peroxisome proliferatoractivated receptor; PUFA, polyunsaturated fatty acids; RCT, randomized clinical trial; T2D, type 2 diabetes; TAG, triacylglycerols; TAG/FA, futile substrate cycle based on hydrolysis of triacylglycerols and reesterification of fatty acids; TZD, thiazolidinediones; VLDL, very-low-density lipoprotein.

\section{References}

ABEL ED, PERONI O, KIM JK, KIM YB, BOSS O, HADRO E, MINNEMANN T, SHULMAN GI, KAHN BB: Adipose-selective targeting of the GLUT4 gene impairs insulin action in muscle and liver. Nature 409: 729-733, 2001.

ADAMS SH: Emerging perspectives on essential amino acid metabolism in obesity and the insulin-resistant state. $A d v$ Nutr 2: 445-456, 2011.

AJIRO K, SAWAMURA M, IKEDA K, NARA Y, NISHIMURA M, ISHIDA H, SEINO Y, YAMORI Y: Beneficial effects of fish oil on glucose metabolism in spontaneously hypertensive rats. Clin Exp Pharmacol Physiol 27: 412-415, 2000.

ALVHEIM AR, MALDE MK, OSEI-HYIAMAN D, LIN YH, PAWLOSKY RJ, MADSEN L, KRISTIANSEN K, FROYLAND L, HIBBELN JR: Dietary linoleic acid elevates endogenous 2-AG and anandamide and induces obesity. Obesity (Silver Spring) 20: 1984-1994, 2012.

AXELROD L, CAMUSO J, WILLIAMS E, KLEINMAN K, BRIONES E, SCHOENFELD D: Effects of a small quantity of omega-3 fatty acids on cardiovascular risk factors in NIDDM. A randomized, prospective, doubleblind, controlled study. Diabetes Care 17: 37-44, 1994.

AZAIN MJ: Role of fatty acids in adipocyte growth and development. J Anim Sci 82: 916-924, 2004.

BALK E, CHUNG M, LIECHTENSTEIN A, CHEW P, KUPELNICK B, LAWRENCE A, DEVINE D, LAU J: Effects of omega-3 fatty acids on cardiovacsular risk factors and intermediate markers of cardivascular disease. Summary, Evidence Report/Technology Assessment: Number 93. Agency for Healthcare Research and Quality, 2004.

BALVERS MG, VERHOECKX KC, BIJLSMA S, RUBINGH CM, MEIJERINK J, WORTELBOER HM, WITKAMP RF: Fish oil and inflammatory status alter the $n-3$ to $n-6$ balance of the endocannabinoid and oxylipin metabolomes in mouse plasma and tissues. Metabolomics 8: 1130-1147, 2012.

BARNES BR, ZIERATH JR: Role of AMP-activated protein kinase in the control of glucose homeostasis. Curr Mol Med 5: 341-348, 2005. 
BATETTA B, GRIINARI M, CARTA G, MURRU E, LIGRESTI A, CORDEDDU L, GIORDANO E, SANNA F, BISOGNO T, UDA S, COLLU M, BRUHEIM I, DI MARZO V, BANNI S: Endocannabinoids may mediate the ability of $(n-3)$ fatty acids to reduce ectopic fat and inflammatory mediators in obese Zucker rats. J Nutr 139: 1495-1501, 2009.

BEHME MT: Dietary fish oil enhances insulin sensitivity in miniature pigs. J Nutr 126: 1549-1553, 1996.

BHATHENA SJ, BERLIN E, JUDD JT, KIM YC, LAW JS, BHAGAVAN HN, BALLARD-BARBASH R, NAIR PP: Effects of omega 3 fatty acids and vitamin $\mathrm{E}$ on hormones involved in carbohydrate and lipid metabolism in men. Am J Clin Nutr 54: 684-688, 1991.

BJERREGAARD P, PEDERSEN HS, MULVAD G: The associations of a marine diet with plasma lipids, blood glucose, blood pressure and obesity among the Inuit in Greenland. Eur J Clin Nutr 54: 732-737, 2000.

BLASBALG TL, HIBBELN JR, RAMSDEN CE, MAJCHRZAK SF, RAWLINGS RR: Changes in consumption of omega-3 and omega-6 fatty acids in the United States during the 20th century. Am J Clin Nutr 93: 950-962, 2011.

BORDIN P, BODAMER OA, VENKATESAN S, GRAY RM, BANNISTER PA, HALLIDAY D: Effects of fish oil supplementation on apolipoprotein B100 production and lipoprotein metabolism in normolipidaemic males. EurJ Clin Nutr 52: 104-109, 1998.

BORKMAN M, CHISHOLM DJ, FURLER SM, STORLIEN LH, KRAEGEN EW, SIMONS LA, CHESTERMAN $\mathrm{CN}$ : Effects of fish oil supplementation on glucose and lipid metabolism in NIDDM. Diabetes 38: 1314-1319, 1989.

BOSCH J, GERSTEIN HC, DAGENAIS GR, DIAZ R, DYAL L, JUNG H, MAGGIONO AP, PROBSTFIELD J, RAMACHANDRAN A, RIDDLE MC, RYDEN LE, YUSUF S: $n-3$ fatty acids and cardiovascular outcomes in patients with dysglycemia. N Engl J Med 367: 309-318, 2012.

BRADY LM, LOVEGROVE SS, LESAUVAGE SV, GOWER BA, MINIHANE AM, WILLIAMS CM, LOVEGROVE JA: Increased $n-6$ polyunsaturated fatty acids do not attenuate the effects of long-chain $n$-3 polyunsaturated fatty acids on insulin sensitivity or triacylglycerol reduction in Indian Asians. Am J Clin Nutr 79: 983-991, 2004.

CALDER PC, YAQOOB P: Omega-3 (n-3) fatty acids, cardiovascular disease and stability of atherosclerotic plaques. Cell Mol Biol (Noisy-le-grand) 56: 28-37, 2010.

CASULA M, SORANNA M, CATAPANO A, CORRAO G: Long-term effect of high dose omega-3 fatty acid supplementation for secondary prevention of cardiovascular outcomes: a meta-analysis of randomized, double blind, placebo controlled trials. Atheroscler Suppl 14: 243-251, 2013.

CHURNRATANAKUL S, KIRDEIKIS KL, MURPHY GK, WIRZBA BJ, KEELAN M, RAJOTTE RV, CLANDININ MT, THOMSON AB: Dietary omega-3 fatty acids partially correct the enhanced in vivo uptake of glucose in diabetic rats. Diabetes Res 15: 117-123, 1990.

CORPELEIJN E, MENSINK M, KOOI ME, ROEKAERTS PM, SARIS WH, BLAAK EE: Impaired skeletal muscle substrate oxidation in glucose-intolerant men improves after weight loss. Obesity (Silver Spring) 16: 1025 1032, 2008.

COUET C, DELARUE J, RITZ P, ANTOINE JM, LAMISSE F: Effect of dietary fish oil on body fat mass and basal fat oxidation in healthy adults. Int J Obes 21: 637-643, 1997.

DANFORTH E JR: Failure of adipocyte differentiation causes type II diabetes mellitus? Nat Genet 26: 13, 2000.

DANGARDT F, CHEN Y, GRONOWITZ E, DAHLGREN J, FRIBERG P, STRANDVIK B: High physiological omega-3 fatty acid supplementation affects muscle fatty acid composition and glucose and insulin homeostasis in obese adolescents. J Nutr Metab 2012: 395757, 2012.

DE LORGERIL M, SALEN P, DEFAYE P, RABAEUS M: Recent findings on the health effects of omega-3 fatty acids and statins, and their interactions: do statins inhibit omega-3? BMC Med 11: 5, 2013.

DELARUE J, COUET C, COHEN R, BRECHOT JF, ANTOINE JM, LAMISSE F: Effects of fish oil on metabolic responses to oral fructose and glucose loads in healthy humans. Am J Physiol 270: E353-E362, 1996.

DELARUE J, LABARTHE F, COHEN R: Fish-oil supplementation reduces stimulation of plasma glucose fluxes during exercise in untrained males. Br J Nutr 90: 777-786, 2003. 
DELARUE J, LEFOLL C, CORPOREAU C, LUCAS D: $n-3$ long chain polyunsaturated fatty acids: a nutritional tool to prevent insulin resistance associated to type 2 diabetes and obesity? Reprod Nutr Dev 44: 289-299, 2004.

DJOUSSE L, BIGGS ML, LEMAITRE RN, KING IB, SONG X, IX JH, MUKAMAL KJ, SISCOVICK DS, MOZAFFARIAN D: Plasma omega-3 fatty acids and incident diabetes in older adults. Am J Clin Nutr 94: 527-533, 2011a.

DJOUSSE L, GAZIANO JM, BURING JE, LEE IM: Dietary omega-3 fatty acids and fish consumption and risk of type 2 diabetes. Am J Clin Nutr 93: 143-150, 2011 b.

DYERBERG J: Linolenate-derived polyunsaturated fatty acids and prevention of atherosclerosis. Nutr Rev 44: 125-134, 1986.

FAEH D, MINEHIRA K, SCHWARZ JM, PERIASAMY R, PARK S, TAPPY L: Effect of fructose overfeeding and fish oil administration on hepatic de novo lipogenesis and insulin sensitivity in healthy men. Diabetes $\mathbf{5 4}$ 1907-1913, 2005.

FASCHING P, RATHEISER K, WALDHAUSL W, ROHAC M, OSTERRODE W, NOWOTNY P, VIERHAPPER H: Metabolic effects of fish-oil supplementation in patients with impaired glucose tolerance. Diabetes 40 : 583-589, 1991.

FESKENS EJ, BOWLES CH, KROMHOUT D: Inverse association between fish intake and risk of glucose intolerance in normoglycemic elderly men and women. Diabetes Care 14: 935-941, 1991.

FESKENS EJ, VIRTANEN SM, RASANEN L, TUOMILEHTO J, STENGARD J, PEKKANEN J, NISSINEN A, KROMHOUT D: Dietary factors determining diabetes and impaired glucose tolerance. A 20-year follow-up of the Finnish and Dutch cohorts of the Seven Countries Study. Diabetes Care 18: 1104-1112, 1995.

FIAMONCINI J, TURNER N, HIRABARA SM, SALGADO TM, MARCAL AC, LESLIE S, DA SILVA SM, DESCHAMPS FC, LUZ J, COONEY GJ, CURI R: Enhanced peroxisomal beta-oxidation is associated with prevention of obesity and glucose intolerance by fish oil-enriched diets. Obesity (Silver Spring) 21: 1200-1207, 2013.

FICKOVA M, HUBERT P, KLIMES I, STAEDEL C, CREMEL G, BOHOV P, MACHO L: Dietary fish oil and olive oil improve the liver insulin receptor tyrosine kinase activity in high sucrose fed rats. Endocr Regul 28: 187-197, 1994.

FLACHS P, HORAKOVA O, BRAUNER P, ROSSMEISL M, PECINA P, FRANSSEN-VAN HAL NL, RUZICKOVA J, SPONAROVA J, DRAHOTA Z, VLCEK C, KEIJER J, HOUSTEK J, KOPECKY J: Polyunsaturated fatty acids of marine origin upregulate mitochondrial biogenesis and induce beta-oxidation in white fat. Diabetologia 48: 2365-2375, 2005.

FLACHS P, MOHAMED-ALI V, HORAKOVA O, ROSSMEISL M, HOSSEINZADEH-ATTAR MJ, HENSLER M, RUZICKOVA J, KOPECKY J: Polyunsaturated fatty acids of marine origin induce adiponectin in mice fed high-fat diet. Diabetologia 49: 394-397, 2006.

FLACHS P, ROSSMEISL M, BRYHN M, KOPECKY J: Cellular and molecular effects of $n$-3 polyunsaturated fatty acids on adipose tissue biology and metabolism. Clin Sci 116: 1-16, 2009.

FLACHS P, RUHL R, HENSLER M, JANOVSKA P, ZOUHAR P, KUS V, MACEK JILKOVA Z, PAPP E, KUDA O, SVOBODOVA M, ROSSMEISL M, TSENOV G, MOHAMED-ALI V, KOPECKY J: Synergistic induction of lipid catabolism and anti-inflammatory lipids in white fat of dietary obese mice in response to calorie restriction and $n-3$ fatty acids. Diabetologia 54: 2626-2638, 2011.

FLACHS P, ROSSMEISL M, KUDA O, KOPECKY J: Stimulation of mitochondrial oxidative capacity in white fat independent of UCP1: A key to lean phenotype. Biochim Biophys Acta 1831: 986-1003, 2013.

FONTANI G, CORRADESCHI F, FELICI A, ALFATTI F, BUGARINI R, FIASCHI AI, CERRETANI D, MONTORFANO G, RIZZO AM, BERRA B: Blood profiles, body fat and mood state in healthy subjects on different diets supplemented with Omega-3 polyunsaturated fatty acids. Eur J Clin Invest 35: 499-507, 2005.

FRIEDBERG CE, JANSSEN MJ, HEINE RJ, GROBBEE DE: Fish oil and glycemic control in diabetes. A metaanalysis. Diabetes Care 21: 494-500, 1998.

FRYER LG, PARBU-PATEL A, CARLING D: The Anti-diabetic drugs rosiglitazone and metformin stimulate AMP-activated protein kinase through distinct signaling pathways. J Biol Chem 277: 25226-25232, 2002. 
GERSTEIN HC, BOSCH J, DAGENAIS GR, DIAZ R, JUNG H, MAGGIONI AP, POGUE J, PROBSTFIELD J, RAMACHANDRAN A, RIDDLE MC, RYDEN LE, YUSUF S: Basal insulin and cardiovascular and other outcomes in dysglycemia. N Engl J Med 367: 319-328, 2012.

GIRON MD, SALTO R, HORTELANO P, PERIAGO JL, VARGAS AM, SUAREZ MD: Increased diaphragm expression of GLUT4 in control and streptozotocin-diabetic rats by fish oil-supplemented diets. Lipids 34: 801-807, 1999

GLASS CK, OLEFSKY JM: Inflammation and lipid signaling in the etiology of insulin resistance. Cell Metab 15: 635-645, 2012.

GLAUBER H, WALLACE P, GRIVER K, BRECHTEL G: Adverse metabolic effect of omega-3 fatty acids in noninsulin-dependent diabetes mellitus. Ann Intern Med 108: 663-668, 1988.

GOH YK, JUMPSEN JA, RYAN EA, CLANDININ MT: Effect of omega 3 fatty acid on plasma lipids, cholesterol and lipoprotein fatty acid content in NIDDM patients. Diabetologia 40: 45-52, 1997.

GONZALEZ-PERIZ A, HORRILLO R, FERRE N, GRONERT K, DONG B, MORAN-SALVADOR E, TITOS E, MARTINEZ-CLEMENTE M, LOPEZ-PARRA M, ARROYO V, CLARIA J: Obesity-induced insulin resistance and hepatic steatosis are alleviated by omega-3 fatty acids: a role for resolvins and protectins. FASEB J 23: 1946-1957, 2009.

GUSTAFSSON IB, OHRVALL M, EKSTRAND B, VESSBY B: No effects on insulin sensitivity but diverging effects on serum free fatty acid concentrations by addition of seafood products containing either $n-3$ or $n-6$ fatty acids. Nutr Metab Cardiovasc Dis 8: 145-153, 1998.

HANSEN HS, DIEP TA: N-acylethanolamines, anandamide and food intake. Biochem Pharmacol 78: 553-560, 2009.

HARRIS WS: The omega-3 index as a risk factor for coronary heart disease. Am J Clin Nutr 87: 1997S-2002S, 2008.

HARRIS WS, THOMAS RM: Biological variability of blood omega-3 biomarkers. Clin Biochem 43: 338-340, 2010.

HELGE JW, WU BJ, WILLER M, DAUGAARD JR, STORLIEN LH, KIENS B: Training affects muscle phospholipid fatty acid composition in humans. $J$ Appl Physiol 90: 670-677, 2001.

HENDRA TJ, BRITTON ME, ROPER DR, WAGAINE-TWABWE D, JEREMY JY, DANDONA P, HAINES AP, YUDKIN JS: Effects of fish oil supplements in NIDDM subjects. Controlled study. Diabetes Care 13: 821-829, 1990.

HENSLER M, BARDOVA K, JILKOVA ZM, WAHLI W, MEZTGER D, CHAMBON P, KOPECKY J, FLACHS P: The inhibition of fat cell proliferation by $n-3$ fatty acids in dietary obese mice. Lipids Health Dis 10: 128, 2011 .

HEVENER AL, HE W, BARAK Y, LE J, BANDYOPADHYAY G, OLSON P, WILKES J, EVANS RM, OLEFSKY J: Muscle-specific Pparg deletion causes insulin resistance. Nat Med 9: 1491-1497, 2003.

HILL AM, BUCKLEY JD, MURPHY KJ, HOWE PR: Combining fish-oil supplements with regular aerobic exercise improves body composition and cardiovascular disease risk factors. Am J Clin Nutr 85: 1267-1274, 2007.

HOJBERG PV, VILSBOLL T, RABOL R, KNOP FK, BACHE M, KRARUP T, HOLST JJ, MADSBAD S: Four weeks of near-normalisation of blood glucose improves the insulin response to glucagon-like peptide-1 and glucose-dependent insulinotropic polypeptide in patients with type 2 diabetes. Diabetologia 52: 199-207, 2009.

HOLNESS MJ, SMITH ND, GREENWOOD GK, SUGDEN MC: Acute omega-3 fatty acid enrichment selectively reverses high-saturated fat feeding-induced insulin hypersecretion but does not improve peripheral insulin resistance. Diabetes 53 (Suppl 1): S166-S171, 2004.

HORAKOVA O, MEDRIKOVA D, VAN SCHOTHORST EM, BUNSCHOTEN A, FLACHS P, KUS V, KUDA O, BARDOVA K, JANOVSKA P, HENSLER M, ROSSMEISL M, WANG-SATTLER R, PREHN C, ADAMSKI J, ILLIG T, KEIJER J, KOPECKY J: Preservation of metabolic flexibility in skeletal muscle by a combined use of $n$-3 PUFA and rosiglitazone in dietary obese mice. Plos One 7: e43764, 2012.

HSIAO G, CHAPMAN J, OFRECIO JM, WILKES J, RESNIK JL, THAPAR D, SUBRAMANIAM S, SEARS DD: Multi-tissue, selective PPARgamma modulation of insulin sensitivity and metabolic pathways in obese rats. Am J Physiol Endocrinol Metab 300: E164-E174, 2011.

HUANG YJ, FANG VS, JUAN CC, CHOU YC, KWOK CF, HO LT: Amelioration of insulin resistance and hypertension in a fructose-fed rat model with fish oil supplementation. Metabolism 46: 1252-1258, 1997. 
HUN CS, HASEGAWA K, KAWABATA T, KATO M, SHIMOKAWA T, KAGAWA Y: Increased uncoupling protein 2 mRNA in white adipose tissue, and decrease in leptin, visceral fat, blood glucose, and cholesterol in KK-Ay mice fed with eicosapentaenoic and docosahexaenoic acids in addition to linolenic acid. Biochem Biophys Res Commun 259: 85-90, 1999.

ITARIU BK, ZEYDA M, HOCHBRUGGER EE, NEUHOFER A, PRAGER G, SCHINDLER K, BOHDJALIAN A, MASCHER D, VANGALA S, SCHRANZ M, KREBS M, BISCHOF MG, STULNIG TM: Long-chain $n$-3 PUFAs reduce adipose tissue and systemic inflammation in severely obese nondiabetic patients: a randomized controlled trial. Am J Clin Nutr 96: 1137-1149, 2012.

ITARIU BK, ZEYDA M, LEITNER L, MARCULESCU R, STULNIG TM: Treatment with $n$-3 polyunsaturated fatty acids overcomes the inverse association of vitamin D deficiency with inflammation in severely obese patients: a randomized controlled trial. Plos One 8: e54634, 2013.

IWAKI M, MATSUDA M, MAEDA N, FUNAHASHI T, MATSUZAWA Y, MAKISHIMA M, SHIMOMURA I: Induction of adiponectin, a fat-derived antidiabetic and antiatherogenic factor, by nuclear receptors. Diabetes 52: 1655-1663, 2003.

JANOVSKA P, FLACHS P, KAZDOVA L, KOPECKY J: Anti-obesity effect of $n-3$ polyunsaturated fatty acids in mice fed high-fat diet is independent of cold-induced thermogenesis. Physiol Res 62: 153-161, 2013.

JELENIK T, ROSSMEISL M, KUDA O, JILKOVA ZM, MEDRIKOVA D, KUS V, HENSLER M, JANOVSKA P, MIKSIK I, BARANOWSKI M, GORSKI J, HEBRARD S, JENSEN TE, FLACHS P, HAWLEY S, VIOLLET $\mathrm{B}, \mathrm{KOPECKY} \mathrm{J:} \mathrm{AMP-activated} \mathrm{protein} \mathrm{kinase}$ alpha\}2 subunit is required for the preservation of hepatic insulin sensitivity by $n-3$ polyunsaturated fatty acids. Diabetes 59: 2737-2746, 2010.

JEPPESEN C, SCHILLER K, SCHULZE MB: Omega-3 and omega-6 fatty acids and type 2 diabetes. Curr Diab Rep 13: 279-288, 2013.

JILKOVA ZM, HENSLER M, MEDRIKOVA D, JANOVSKA P, HORAKOVA O, ROSSMEISL M, FLACHS P, SELL H, ECKEL J, KOPECKY J: Adipose tissue-related proteins locally associated with resolution of inflammation in obese mice. Int J Obes (Lond): 2013 (in press).

JONKER JW, SUH JM, ATKINS AR, AHMADIAN M, LI P, WHYTE J, HE M, JUGUILON H, YIN YQ, PHILLIPS CT, YU RT, OLEFSKY JM, HENRY RR, DOWNES M, EVANS RM: A PPARgamma-FGF1 axis is required for adaptive adipose remodelling and metabolic homeostasis. Nature 485: 391-394, 2012.

JUAREZ-LOPEZ C, KLUNDER-KLUNDER M, MADRIGAL-AZCARATE A, FLORES-HUERTA S: Omega-3 polyunsaturated fatty acids reduce insulin resistance and triglycerides in obese children and adolescents. Pediatr Diabetes 14: 377-383, 2013.

KASIM SE, STERN B, KHILNANI S, MCLIN P, BACIOROWSKI S, JEN KL: Effects of omega-3 fish oils on lipid metabolism, glycemic control, and blood pressure in type II diabetic patients. J Clin Endocrinol Metab 67: 1-5, 1988.

KAUSHIK M, MOZAFFARIAN D, SPIEGELMAN D, MANSON JE, WILLETT WC, HU FB: Long-chain omega-3 fatty acids, fish intake, and the risk of type 2 diabetes mellitus. Am J Clin Nutr 90: 613-620, 2009.

KESAVULU MM, KAMESWARARAO B, APPARAO C, KUMAR EG, HARINARAYAN CV: Effect of omega-3 fatty acids on lipid peroxidation and antioxidant enzyme status in type 2 diabetic patients. Diabetes Metab 28: 20-26, 2002.

KINTSCHER U, LAW RE: PPARgamma-mediated insulin sensitization: the importance of fat versus muscle. $A m \mathrm{~J}$ Physiol Endocrinol Metab 288: E287-E291, 2005.

KLIMES I, SEBOKOVA E, VRANA A, KAZDOVA L: Raised dietary intake of $n-3$ polyunsaturated fatty acids in high sucrose-induced insulin resistance. Animal studies. Ann N Y Acad Sci 683: 69-81, 1993.

KNOWLER WC, BARRETT-CONNOR E, FOWLER SE, HAMMAN RF, LACHIN JM, WALKER EA, NATHAN DM: Reduction in the incidence of type 2 diabetes with lifestyle intervention or metformin. $N$ Engl J Med 346: 393-403, 2002.

KOPECKY J, ROSSMEISL M, FLACHS P, KUDA O, BRAUNER P, JILKOVA Z, STANKOVA B, TVRZICKA E, BRYHN M: $n$-3 PUFA: bioavailability and modulation of adipose tissue function Proc Nutr Soc 68: 361-369, 2009. 
KOPELMAN PG: Obesity as a medical problem. Nature 404: 635-643, 2000.

KREBS JD, BROWNING LM, MCLEAN NK, ROTHWELL JL, MISHRA GD, MOORE CS, JEBB SA: Additive benefits of long-chain $n-3$ polyunsaturated fatty acids and weight-loss in the management of cardiovascular disease risk in overweight hyperinsulinaemic women. Int J Obes (Lond) 30: 1535-1544, 2006.

KROMHOUT D, GILTAY EJ, GELEIJNSE JM: $n-3$ fatty acids and cardiovascular events after myocardial infarction. NEngl J Med 363: 2015-2026, 2010.

KROMHOUT D, GELEIJNSE JM, DE GOEDE J, OUDE GRIEP LM, MULDER BJ, DE BOER MJ, DECKERS JW, BOERSMA E, ZOCK PL, GILTAY EJ: n-3 fatty acids, ventricular arrhythmia-related events, and fatal myocardial infarction in postmyocardial infarction patients with diabetes. Diabetes Care 34: 2515-2520, 2011.

KUDA O, JILKOVA Z, ROSSMEISL M, FLACHS P, OGSTON NC: Synergistic effects of $n$ - 3 polyunsaturated fatty acids and rosiglitazone in the amelioration of insulin resistance and ddipose tissue inflammation. Diabetologia 50: S260-S260, 2007.

KUDA O, JELENIK T, JILKOVA Z, FLACHS P, ROSSMEISL M, HENSLER M, KAZDOVA L, OGSTON N, BARANOWSKI M, GORSKI J, JANOVSKA P, KUS V, POLAK J, MOHAMED-ALI V, BURCELIN R, CINTI S, BRYHN M, KOPECKY J: $n-3$ fatty acids and rosiglitazone improve insulin sensitivity through additive stimulatory effects on muscle glycogen synthesis in mice fed a high-fat diet. Diabetologia 52: 941-951, 2009.

KUNESOVA M, BRAUNEROVA R, HLAVATY P, TVRZICKA E, STANKOVA B, SKRHA J, HILGERTOVA J, HILL M, KOPECKY J, WAGENKNECHT M, HAINER V, MATOULEK M, PARIZKOVA J, ZAK A, SVACINA S: The influence of $n-3$ polyunsaturated fatty acids and very low calorie diet during a short-term weight reducing regimen on weight loss and serum fatty acid composition in severely obese women. Physiol Res 55: 63-72, 2006.

KUS V, FLACHS P, KUDA O, BARDOVA K, JANOVSKA P, SVOBODOVA M, JILKOVA ZM, ROSSMEISL M, WANG-SATTLER R, YU Z, ILLIG T, KOPECKY J: Unmasking differential effects of rosiglitazone and pioglitazone in the combination treatment with $n$-3 fatty acids in mice fed a high-fat diet. Plos One 6: e27126e27127, 2011.

KWAK SM, MYUNG SK, LEE YJ, SEO HG, KOREAN META-ANALYSIS STUDY GROUP: Efficacy of omega-3 fatty acid supplements (eicosapentaenoic acid and docosahexaenoic acid) in the secondary prevention of cardiovascular disease: a meta-analysis of randomized, double-blind, placebo-controlled trials. Arch Intern Med 172: 686-694, 2012.

LAHOZ C, ALONSO R, PORRES A, MATA P: Diets enriched with monounsaturated fatty acids and omega-3 polyunsaturated fatty acids decrease blood pressure without changing the plasma insulin concentration in healthy subjects (in Spanish). Med Clin (Barc) 112: 133-137, 1999.

LAI YH, PETRONE AB, PANKOW JS, ARNETT DK, NORTH KE, ELLISON RC, HUNT SC, DJOUSSE L: Association of dietary omega-3 fatty acids with prevalence of metabolic syndrome: The National Heart, Lung, and Blood Institute Family Heart Study. Clin Nutr 32: 966-969, 2013.

LEBRASSEUR NK, KELLY M, TSAO TS, FARMER SR, SAHA AK, RUDERMAN NB, TOMAS E: Thiazolidinediones can rapidly activate AMP-activated protein kinase (AMPK) in mammalian tissues. Am J Physiol Endocrinol Metab 291: E175-E181, 2006.

LINN T, NOKE M, WOEHRLE M, KLOER HU, HAMMES HP, LITZLBAUER D, BRETZEL RG, FEDERLIN K: Fish oil-enriched diet and reduction of low-dose streptozocin-induced hyperglycemia. Inhibition of macrophage activation. Diabetes 38: 1402-1411, 1989.

LOMBARDO YB, CHICCO A, D'ALESSANDRO ME, MARTINELLI M, SORIA A, GUTMAN R: Dietary fish oil normalize dyslipidemia and glucose intolerance with unchanged insulin levels in rats fed a high sucrose diet. Biochim Biophys Acta 1299: 175-182, 1996.

LOMBARDO YB, CHICCO AG: Effects of dietary polyunsaturated $n-3$ fatty acids on dyslipidemia and insulin resistance in rodents and humans. A review. J Nutr Biochem 17: 1-13, 2006. 
LOPEZ-ALARCON M, MARTINEZ-CORONADO A, VELARDE-CASTRO O, RENDON-MACIAS E, FERNANDEZ J: Supplementation of $n$-3 long-chain polyunsaturated fatty acid synergistically decreases insulin resistance with weight loss of obese prepubertal and pubertal children. Arch Med Res 42: 502-508, 2011.

LORENTE-CEBRIAN S, COSTA AG, NAVAS-CARRETERO S, ZABALA M, MARTINEZ JA, MORENOALIAGA MJ: Role of omega-3 fatty acids in obesity, metabolic syndrome, and cardiovascular diseases: a review of the evidence. $J$ Physiol Biochem 69: 633-651, 2013.

LOWELL BB, SHULMAN GI: Mitochondrial dysfunction and type 2 diabetes. Science 307: 384-387, 2005.

LUQUET S, GAUDEL C, HOLST D, LOPEZ-SORIANO J, JEHL-PIETRI C, FREDENRICH A, GRIMALDI PA: Roles of PPAR delta in lipid absorption and metabolism: a new target for the treatment of type 2 diabetes. Biochim Biophys Acta 1740: 313-317, 2005.

MACLEAN CH, MOJICA WA, MORTON SC, PENCHARZ J, HASENFELD GARLAND R, TU W, NEWBERRY SJ, JUNGVIG LK: Effects of omega-3 fatty acids on lipids and glycemic control in type II diabetes and the metabolic syndrome and on inflammatory bowel disease, rheumatoid arthritis, renal disease, systemic lupus erythrematosus, and osteoporosis. Summary, Evidence Report/Technology Assessment: Number 89. Agency for Healthcare Research and Quality, 2004.

MADSEN L, PETERSEN RK, KRISTIANSEN K: Regulation of adipocyte differentiation and function by polyunsaturated fatty acids. Biochim Biophys Acta 1740: 266-286, 2005.

MAKI KC, REEVES MS, FARMER M, GRIINARI M, BERGE K, VIK H, HUBACHER R, RAINS TM: Krill oil supplementation increases plasma concentrations of eicosapentaenoic and docosahexaenoic acids in overweight and obese men and women. Nutr Res 29: 609-615, 2009.

MARCKMANN P, BLADBJERG EM, JESPERSEN J: Dietary fish oil (4 g daily) and cardiovascular risk markers in healthy men. Arterioscler Thromb Vasc Biol 17: 3384-3391, 1997.

MARCHIOLI R: Dietary supplementation with $n-3$ polyunsaturated fatty acids and vitamin E after myocardial infarction: results of the GISSI-Prevenzione trial. Gruppo Italiano per lo Studio della Sopravvivenza nell'Infarto miocardico. Lancet 354: 447-455, 1999.

MATSUURA B, KANNO S, MINAMI H, TSUBOUCHI E, IWAI M, MATSUI H, HORIIKE N, ONJI M: Effects of antihyperlipidemic agents on hepatic insulin sensitivity in perfused Goto-Kakizaki rat liver. $J$ Gastroenterol 39: 339-345, 2004.

MCGRATH LT, BRENNAN GM, DONNELLY JP, JOHNSTON GD, HAYES JR, MCVEIGH GE: Effect of dietary fish oil supplementation on peroxidation of serum lipids in patients with non-insulin dependent diabetes mellitus. Atherosclerosis 121: 275-283, 1996.

MCMANUS RM, JUMPSON J, FINEGOOD DT, CLANDININ MT, RYAN EA: A comparison of the effects of $n$-3 fatty acids from linseed oil and fish oil in well-controlled type II diabetes. Diabetes Care 19: 463-467, 1996.

MEDRIKOVA D, JILKOVA ZM, BARDOVA K, JANOVSKA P, ROSSMEISL M, KOPECKY J: Sex differences during the course of diet-induced obesity in mice: adipose tissue expandability and glycemic control. Int $J$ Obes 36: 262-272, 2011.

MICALLEF M, MUNRO I, PHANG M, GARG M: Plasma $n-3$ polyunsaturated fatty acids are negatively associated with obesity. Br J Nutr 102: 1370-1374, 2009.

MINAMI A, ISHIMURA N, SAKAMOTO S, TAKISHITA E, MAWATARI K, OKADA K, NAKAYA Y: Effect of eicosapentaenoic acid ethyl ester v. oleic acid-rich safflower oil on insulin resistance in type 2 diabetic model rats with hypertriacylglycerolaemia1. Br J Nutr 87: 157-162, 2002.

MINIHANE AM, BRADY LM, LOVEGROVE SS, LESAUVAGE SV, WILLIAMS CM, LOVEGROVE JA: Lack of effect of dietary $n-6: n-3$ PUFA ratio on plasma lipids and markers of insulin responses in Indian Asians living in the UK. Eur J Nutr 44: 26-32, 2005.

MINOKOSHI Y, KIM YB, PERONI OD, FRYER LG, MULLER C, CARLING D, KAHN BB: Leptin stimulates fattyacid oxidation by activating AMP-activated protein kinase1. Nature 415: 339-343, 2002.

MONTORI VM, FARMER A, WOLLAN PC, DINNEEN SF: Fish oil supplementation in type 2 diabetes: a quantitative systematic review. Diabetes Care 23: 1407-1415, 2000. 
MORI TA, BAO DQ, BURKE V, PUDDEY IB, WATTS GF, BEILIN LJ: Dietary fish as a major component of a weight-loss diet: effect on serum lipids, glucose, and insulin metabolism in overweight hypertensive subjects. Am J Clin Nutr 70: 817-825, 1999.

MORISHITA M, TANAKA T, SHIDA T, TAKAYAMA K: Usefulness of colon targeted DHA and EPA as novel diabetes medications that promote intrinsic GLP-1 secretion. J Control Release 132: 99-104, 2008.

MOSTAD IL, BJERVE KS, BJORGAAS MR, LYDERSEN S, GRILL V: Effects of $n$ - 3 fatty acids in subjects with type 2 diabetes: reduction of insulin sensitivity and time-dependent alteration from carbohydrate to fat oxidation. Am J Clin Nutr 84: 540-550, 2006.

MOSTAD IL, BJERVE KS, BASU S, SUTTON P, FRAYN KN, GRILL V: Addition of $n$-3 fatty acids to a 4-hour lipid infusion does not affect insulin sensitivity, insulin secretion, or markers of oxidative stress in subjects with type 2 diabetes mellitus. Metabolism 58: 1753-1761, 2009.

MOZAFFARIAN D, LEMAITRE RN, KING IB, SONG X, HUANG H, SACKS FM, RIMM EB, WANG M, SISCOVICK DS: Plasma phospholipid long-chain omega-3 fatty acids and total and cause-specific mortality in older adults: a cohort study. Ann Intern Med 158: 515-525, 2013.

MUDALIAR S, HENRY RR: The incretin hormones: from scientific discovery to practical therapeutics. Diabetologia 55: 1865-1868, 2012.

MUOIO DM, NEUFER PD: Lipid-induced mitochondrial stress and insulin action in muscle. Cell Metab 15: 595-605, 2012.

NAKAMURA T, AZUMA A, KURIBAYASHI T, SUGIHARA H, OKUDA S, NAKAGAWA M: Serum fatty acid levels, dietary style and coronary heart disease in three neighbouring areas in Japan: the Kumihama study. $B r J$ Nutr 89: 267-272, 2003.

NAUCK M, STOCKMANN F, EBERT R, CREUTZFELDT W: Reduced incretin effect in type 2 (non-insulindependent) diabetes. Diabetologia 29: 46-52, 1986.

NAUCK MA: Incretin-based therapies for type 2 diabetes mellitus: properties, functions, and clinical implications. $\mathrm{Am}$ J Med 124 (1 Suppl): S3-S18, 2011.

NESCHEN S, MORINO K, ROSSBACHER JC, PONGRATZ RL, CLINE GW, SONO S, GILLUM M, SHULMAN GI: Fish oil regulates adiponectin secretion by a peroxisome proliferator-activated receptor-gamma-dependent mechanism in mice. Diabetes 55: 924-928, 2006.

NESCHEN S, MORINO K, DONG J, WANG-FISCHER Y, CLINE GW, ROMANELLI AJ, ROSSBACHER JC, MOORE IK, REGITTNIG W, MUNOZ DS, KIM JH, SHULMAN GI: $n-3$ fatty acids preserve insulin sensitivity in vivo in a PPAR \{alpha\}-dependent manner. Diabetes 56: 1034-1041, 2007.

NEUBRONNER J, SCHUCHARDT JP, KRESSEL G, MERKEL M, vON SCHACKY C, HAHN A: Enhanced increase of omega-3 index in response to long-term $n-3$ fatty acid supplementation from triacylglycerides versus ethyl esters. Eur J Clin Nutr 65: 247-254, 2011.

NEUHOFER A, ZEYDA M, MASCHER D, ITARIU BK, MURANO I, LEITNER L, HOCHBRUGGER EE, FRAISL P, CINTI S, SERHAN CN, STULNIG TM: Impaired local production of proresolving lipid mediators in obesity and 17-HDHA as a potential treatment for obesity-associated inflammation. Diabetes 62: 1945-1956, 2013.

NEWGARD CB: Interplay between lipids and branched-chain amino acids in development of insulin resistance. Cell Metab 15: 606-614, 2012.

NEWGARD CB, AN J, BAIN JR, MUEHLBAUER MJ, STEVENS RD, LIEN LF, HAQQ AM, SHAH SH, ARLOTTO M, SLENTZ CA, ROCHON J, GALLUP D, ILKAYEVA O, WENNER BR, YANCY WS JR, EISENSON H, MUSANTE G, SURWIT RS, MILLINGTON DS, BUTLER MD, SVETKEY LP: A branchedchain amino acid-related metabolic signature that differentiates obese and lean humans and contributes to insulin resistance. Cell Metab 9: 311-326, 2009.

NEWMAN RE, BRYDEN WL, FLECK E, ASHES JR, BUTTEMER WA, STORLIEN LH, DOWNING JA: Dietary $n-3$ and $n-6$ fatty acids alter avian metabolism: metabolism and abdominal fat deposition. Br J Nutr 88: 11-18, 2002 . 
NOBUKATA H, ISHIKAWA T, OBATA M, SHIBUTANI Y: Long-term administration of highly purified eicosapentaenoic acid ethyl ester prevents diabetes and abnormalities of blood coagulation in male WBN/Kob rats. Metabolism 49: 912-919, 2000.

OIKAWA S, YOKOYAMA M, ORIGASA H, MATSUZAKI M, MATSUZAWA Y, SAITO Y, ISHIKAWA Y, SASAKI J, HISHIDA H, ITAKURA H, KITA T, KITABATAKE A, NAKAYA N, SAKATA T, SHIMADA K, SHIRATO K, JELIS INVESTIGATORS JAPAN: Suppressive effect of EPA on the incidence of coronary events in hypercholesterolemia with impaired glucose metabolism: Sub-analysis of the Japan EPA Lipid Intervention Study (JELIS). Atherosclerosis 206: 535-539, 2009.

OKUNO A, TAMEMOTO H, TOBE K, UEKI K, MORI Y, IWAMOTO K, UMESONO K, AKANUMA Y, FUJIWARA T, HORIKOSHI H, YAZAKI Y, KADOWAKI T: Troglitazone increases the number of small adipocytes without the change of white adipose tissue mass in obese zucker rats. $J$ Clin Invest 101: 1354-1361, 1998.

OVIDE-BORDEAUX S, GRYNBERG A: Docosahexaenoic acid affects insulin deficiency- and insulin resistanceinduced alterations in cardiac mitochondria. Am J Physiol Regul Integr Comp Physiol 286: R519-R527, 2004.

PATEL PS, FOROUHI NG, KUIJSTEN A, SCHULZE MB, VAN WOUDENBERGH GJ, ARDANAZ E, AMIANO P, ARRIOLA L, BALKAU B, BARRICARTE A, BEULENS JW, BOEING H, BUIJSSE B, CROWE FL, DE LAUZON-GUILLAN B, FAGHERAZZI G, FRANKS PW, GONZALEZ C, GRIONI S, HALKJAER J, HUERTA JM, KEY TJ, KUHN T, MASALA G, NILSSON P, OVERVAD K, PANICO S, QUIROS JR, ROLANDSSON O, SACERDOTE C, SANCHEZ MJ, SCHMIDT EB, SLIMANI N, SPIJKERMAN AM, TEUCHER B, TJONNELAND A, TORMO MJ, TUMINO R, VAN DER A DL, VAN DER SCHOUW YT, SHARP SJ, LANGENBERG C, FESKENS EJ, RIBOLI E, WAREHAM NJ: The prospective association between total and type of fish intake and type 2 diabetes in 8 European countries: EPIC-InterAct Study. Am J Clin Nutr 95: 1445-1453, 2012.

PELIKANOVA T, KOHOUT M, VALEK J, KAZDOVA L, BASE J: Metabolic effects of omega-3 fatty acids in type 2 (non-insulin-dependent) diabetic patients. Ann N Y Acad Sci 683: 272-278, 1993.

PEYRON-CASO E, FLUTEAU-NADLER S, KABIR M, GUERRE-MILLO M, QUIGNARD-BOULANGE A, SLAMA G, RIZKALLA SW: Regulation of glucose transport and transporter 4 (GLUT-4) in muscle and adipocytes of sucrose-fed rats: effects of $n-3$ poly- and monounsaturated fatty acids. Horm Metab Res 34: 360-366, 2002.

PIETILAINEN KH, SYSI-AHO M, RISSANEN A, SEPPANEN-LAAKSO T, YKI-JARVINEN H, KAPRIO J, ORESIC M: Acquired obesity is associated with changes in the serum lipidomic profile independent of genetic effects--a monozygotic twin study. PLoS One 2: e218, 2007.

PIGHIN D, KARABATAS L, ROSSI A, CHICCO A, BASABE JC, LOMBARDO YB: Fish oil affects pancreatic fat storage, pyruvate dehydrogenase complex activity and insulin secretion in rats fed a sucrose-rich diet. $J$ Nutr 133: 4095-4101, 2003.

PODOLIN DA, GAYLES EC, WEI Y, THRESHER JS, PAGLIASSOTTI MJ: Menhaden oil prevents but does not reverse sucrose-induced insulin resistance in rats. Am J Physiol 274: R840-R848, 1998.

POOLE CD, HALCOX JP, JENKINS-JONES S, CARR ES, SCHIFFLERS MG, RAY KK, CURRIE CJ: Omega-3 fatty acids and mortality outcome in patients with and without type 2 diabetes after myocardial infarction: a retrospective, matched-cohort study. Clin Ther 35: 40-51, 2013.

RAKHSHANDEHROO M, HOOIVELD G, MULLER M, KERSTEN S: Comparative analysis of gene regulation by the transcription factor PPARalpha between mouse and human. Plos One 4: e6796, 2009.

RAMEL A, MARTINEZ A, KIELY M, MORAIS G, BANDARRA NM, THORSDOTTIR I: Beneficial effects of long-chain $n$-3 fatty acids included in an energy-restricted diet on insulin resistance in overweight and obese European young adults. Diabetologia 51: 1261-1268, 2008.

RAUCH B, SCHIELE R, SCHNEIDER S, DILLER F, VICTOR N, GOHLKE H, GOTTWIK M, STEINBECK G, DEL CASTILLO U, SACK R, WORTH H, KATUS H, SPITZER W, SABIN G, SENGES J, GROUP OS: OMEGA, a randomized, placebo-controlled trial to test the effect of highly purified omega-3 fatty acids on top of modern guideline-adjusted therapy after myocardial infarction. Circulation 122: 2152-2159, 2010. 
RIUS B, LOPEZ-VICARIO C, GONZALEZ-PERIZ A, MORAN-SALVADOR E, GARCIA-ALONSO V, CLARIA J, TITOS E: Resolution of inflammation in obesity-induced liver disease. Front Immunol 3: 257, 2012.

RONCAGLIONI MC, TOMBESI M, AVANZINI F, BARLERA S, CAIMI V, LONGONI P, MARZONA I, MILANI V, SILLETTA M, TOGNONI G, MARCHIOLI R: $n$-3 fatty acids in patients with multiple cardiovascular risk factors. $N$ Engl J Med 368: 1800-1808, 2013.

ROSSI AS, LOMBARDO YB, LACORTE JM, CHICCO AG, ROUAULT C, SLAMA G, RIZKALLA SW: Dietary fish oil positively regulates plasma leptin and adiponectin levels in sucrose-fed, insulin-resistant rats. $A m J$ Physiol Regul Integr Comp Physiol 289: R486-R494, 2005.

ROSSMEISL M, JELENIK T, JILKOVA Z, SLAMOVA K, KUS V, HENSLER M, MEDRIKOVA D, POVYSIL C, FLACHS P, MOHAMED-ALI V, BRYHN M, BERGE K, HOLMEIDE AK, KOPECKY J: Prevention and reversal of obesity and glucose intolerance in mice by DHA derivatives. Obesity 17: 1023-1031, 2009.

ROSSMEISL M, MACEK JZ, KUDA O, JELENIK T, MEDRIKOVA D, STANKOVA B, KRISTINSSON B, HARALDSSON GG, SVENSEN H, STOKNES I, SJOVALL P, MAGNUSSON Y, BALVERS MG, VERHOECKX KC, TVRZICKA E, BRYHN M, KOPECKY J: Metabolic effects of $n$-3 PUFA as phospholipids are superior to triglycerides in mice fed a high-fat diet: possible role of endocannabinoids. Plos One 7: e38834, 2012.

ROSSMEISL M, MEDRIKOVA D, VAN SCHOTHORST EM, PAVLISOVA J, KUDA O, HENSLER M, BARDOVA K, FLACHS P, STANKOVA B, VECKA M, TVRZICKA E, ZAK A, KEIJER J, KOPECKY J: Omega-3 phospholipids from fish suppress hepatic steatosis by integrated inhibition of biosynthetic pathways in dietary obese mice. Biochim Biophys Acta 1841: 267-278, 2014.

RUZICKOVA J, ROSSMEISL M, PRAZAK T, FLACHS P, SPONAROVA J, VECKA M, TVRZICKA E, BRYHN M, KOPECKY J: Omega-3 PUFA of marine origin limit diet-induced obesity in mice by reducing cellularity of adipose tissue. Lipids 39: 1177-1185, 2004.

RYDEN L, GRANT PJ, ANKER SD, BERNE C, COSENTINO F, DANCHIN N, DEATON C, ESCANED J, HAMMES HP, HUIKURI H, MARRE M, MARX N, MELLBIN L, OSTERGREN J, PATRONO C, SEFEROVIC P, UVA MS, TASKINEN MR, TENDERA M, TUOMILEHTO J, VALENSI P, ZAMORANO JL, GUIDELINES ESCCFP, ZAMORANO JL, ACHENBACH S, BAUMGARTNER H, BAX JJ, BUENO H, DEAN V, DEATON C, EROL C, FAGARD R, FERRARI R, HASDAI D, HOES AW, KIRCHHOF P, KNUUTI J, KOLH P, LANCELLOTTI P, LINHART A, NIHOYANNOPOULOS P, PIEPOLI MF, PONIKOWSKI P, SIRNES PA, TAMARGO JL, TENDERA M, TORBICKI A, WIJNS W, WINDECKER S, DOCUMENT R, DE BACKER G, SIRNES PA, EZQUERRA EA, AVOGARO A, BADIMON L, BARANOVA E, BAUMGARTNER H, BETTERIDGE J, CERIELLO A, FAGARD R, FUNCK-BRENTANO C, GULBA DC, HASDAI D, HOES AW, KJEKSHUS JK, KNUUTI J, KOLH P, LEV E, MUELLER C, NEYSES L, NILSSON PM, PERK J, PONIKOWSKI P, REINER Z, SATTAR N, SCHACHINGER V, SCHEEN A, SCHIRMER H, STROMBERG A, SUDZHAEVA S, TAMARGO JL, VIIGIMAA M, VLACHOPOULOS C, XUEREB RG: ESC Guidelines on diabetes, pre-diabetes, and cardiovascular diseases developed in collaboration with the EASD: the Task Force on diabetes, pre-diabetes, and cardiovascular diseases of the European Society of Cardiology (ESC) and developed in collaboration with the European Association for the Study of Diabetes (EASD). Eur Heart J 34: 3035-3087, 2013.

SARBOLOUKI S, JAVANBAKHT MH, DERAKHSHANIAN H, HOSSEINZADEH P, ZAREEI M, HASHEMI SB, DOROSTY AR, ESHRAGHIAN MR, DJALALI M: Eicosapentaenoic acid improves insulin sensitivity and blood sugar in overweight type 2 diabetes mellitus patients: a double-blind randomised clinical trial. Singapore Med J 54: 387-390, 2013.

SERHAN CN, PETASIS NA: Resolvins and protectins in inflammation resolution. Chem Rev 111: 5922-5943, 2011.

SESHASAI SR, KAPTOGE S, THOMPSON A, Di ANGELANTONIO E, GAO P, SARWAR N, WHINCUP PH, MUKAMAL KJ, GILLUM RF, HOLME I, NJOLSTAD I, FLETCHER A, NILSSON P, LEWINGTON S, COLLINS R, GUDNASON V, THOMPSON SG, SATTAR N, SELVIN E, HU FB, DANESH J: Diabetes mellitus, fasting glucose, and risk of cause-specific death. $N$ Engl J Med 364: 829-841, 2011. 
SHIMURA T, MIURA T, USAMI M, ISHIHARA E, TANIGAWA K, ISHIDA H, SEINO Y: Docosahexanoic acid (DHA) improved glucose and lipid metabolism in KK-Ay mice with genetic non-insulin-dependent diabetes mellitus (NIDDM). Biol Pharm Bull 20: 507-510, 1997.

SCHUCHARDT JP, HAHN A: Bioavailability of long-chain omega-3 fatty acids. Prostaglandins Leukot Essent Fatty Acids 89: 1-8, 2013.

SCHUCHARDT JP, SCHNEIDER I, MEYER H, NEUBRONNER J, vON SCHACKY C, HAHN A: Incorporation of EPA and DHA into plasma phospholipids in response to different omega-3 fatty acid formulations - a comparative bioavailability study of fish oil vs. krill oil. Lipids Health Dis 10: 145, 2011.

SIRTORI CR, PAOLETTI R, MANCINI M, CREPALDI G, MANZATO E, RIVELLESE A, PAMPARANA F, STRAGLIOTTO E: $n$-3 fatty acids do not lead to an increased diabetic risk in patients with hyperlipidemia and abnormal glucose tolerance. Italian Fish Oil Multicenter Study. Am J Clin Nutr 65: 1874-1881, 1997.

SKURNICK-MINOT G, LAROMIGUIERE M, OPPERT JM, QUIGNARD-BOULANGE A, BOILLOT J, RIGOIR A, SLAMA G, RIZKALLA SW: Whole-body fat mass and insulin sensitivity in type 2 diabetic women: effect of n-3 polyunsaturated fatty acids. Diabetes 53 (Suppl 2): A44, 2004.

SMITH WL: Cyclooxygenases, peroxide tone and the allure of fish oil. Curr Opin Cell Biol 17: 174-182, 2005.

STEERENBERG PA, BEEKHOF PK, FESKENS EJ, LIPS CJ, HOPPENER JW, BEEMS RB: Long-term effect of fish oil diet on basal and stimulated plasma glucose and insulin levels in ob/ob mice. Diabetes Nutr Metab 15: 205-214, 2002.

STORLIEN LH, KRAEGEN EW, CHISHOLM DJ, FORD GL, BRUCE DG, PASCOE WS: Fish oil prevents insulin resistance induced by high-fat feeding in rats. Science 237: 885-888, 1987.

STORLIEN LH, JENKINS AB, CHISHOLM DJ, PASCOE WS, KHOURI S, KRAEGEN EW: Influence of dietary fat composition on development of insulin resistance in rats. Relationship to muscle triglyceride and omega-3 fatty acids in muscle phospholipid. Diabetes 40: 280-289, 1991.

SUGII S, OLSON P, SEARS DD, SABERI M, ATKINS AR, BARISH GD, HONG SH, CASTRO GL, YIN YQ, NELSON MC, HSIAO G, GREAVES DR, DOWNES M, YU RT, OLEFSKY JM, EVANS RM: PPARgamma activation in adipocytes is sufficient for systemic insulin sensitization. Proc Natl Acad Sci USA 106: 2250422509, 2009.

SUCHANKOVA G, TEKLE M, SAHA AK, RUDERMAN NB, CLARKE SD, GETTYS TW: Dietary polyunsaturated fatty acids enhance hepatic AMP-activated protein kinase activity in rats. Biochem Biophys Res Commun 326: 851-858, 2005.

TAKAHASHI Y, IDE T: Dietary $n-3$ fatty acids affect mRNA level of brown adipose tissue uncoupling protein 1 , and white adipose tissue leptin and glucose transporter 4 in the rat. Br J Nutr 84: 175-184, 2000.

THORSDOTTIR I, TOMASSON H, GUNNARSDOTTIR I, GISLADOTTIR E, KIELY M, PARRA MD, BANDARRA NM, SCHAAFSMA G, MARTINEZ JA: Randomized trial of weight-loss-diets for young adults varying in fish and fish oil content. Int J Obes (Lond) 31: 1560-1566, 2007.

TUOMILEHTO J, LINDSTROM J, ERIKSSON JG, VALLE TT, HAMALAINEN H, ILANNE-PARIKKA P, KEINANEN-KIUKAANNIEMI S, LAAKSO M, LOUHERANTA A, RASTAS M, SALMINEN V, UUSITUPA M: Prevention of type 2 diabetes mellitus by changes in lifestyle among subjects with impaired glucose tolerance. $N$ Engl J Med 344: 1343-1350, 2001.

ULVEN SM, KIRKHUS B, LAMGLAIT A, BASU S, ELIND E, HAIDER T, BERGE K, VIK H, PEDERSEN JI: Metabolic effects of krill oil are essentially similar to those of fish oil but at lower dose of EPA and DHA, in healthy volunteers. Lipids 46: 37-46, 2011.

VAN SCHOTHORST EM, FLACHS P, FRANSSEN-VAN HAL NL, KUDA O, BUNSCHOTEN A, MOLTHOFF J, VINK C, HOOIVELD GJ, KOPECKY J, KEIJER J: Induction of lipid oxidation by polyunsaturated fatty acids of marine origin in small intestine of mice fed a high-fat diet. BMC Genomics 10: 110, 2009.

VESSBY B, BOBERG M: Dietary supplementation with $n-3$ fatty-acids may impair glucose-homeostasis in patients with non-insulin-dependent diabetes-mellitus. J Intern Med 228: 165-171, 1990. 
VIRTANEN JK, MURSU J, VOUTILAINEN S, UUSITUPA M, TUOMAINEN TP: Serum omega-3 polyunsaturated fatty acids and risk of incident type 2 diabetes in men: the Kuopio Ischaemic Heart Disease Risk Factor Study. Diabetes Care 37: 189-196, 2014.

VIRTUE S, VIDAL-PUIG A: Adipose tissue expandability, lipotoxicity and the metabolic syndrome - an allostatic perspective. Biochim Biophys Acta 1801: 338-349, 2010.

WANG J, UEDA N: Biology of endocannabinoid synthesis system. Prostaglandins Other Lipid Mediat 89: 112-119, 2009.

WARNER JG JR, ULLRICH IH, ALBRINK MJ, YEATER RA: Combined effects of aerobic exercise and omega-3 fatty acids in hyperlipidemic persons. Med Sci Sports Exerc 21: 498-505, 1989.

WILLIAMS CM, MOORE F, MORGAN L, WRIGHT J: Effects of $n-3$ fatty acids on postprandial triacylglycerol and hormone concentrations in normal subjects. Br J Nutr 68: 655-666, 1992.

WILSON-FRITCH L, NICOLORO S, CHOUINARD M, LAZAR MA, CHUI PC, LESZYK J, STRAUBHAAR J, CZECH MP, CORVERA S: Mitochondrial remodeling in adipose tissue associated with obesity and treatment with rosiglitazone. J Clin Invest 114: 1281-1289, 2004.

WU JH, LEMAITRE RN, KING IB, SONG X, SACKS FM, RIMM EB, HECKBERT SR, SISCOVICK DS, MOZAFFARIAN D: Association of plasma phospholipid long-chain omega-3 fatty acids with incident atrial fibrillation in older adults: the cardiovascular health study. Circulation 125: 1084-1093, 2012a.

WU JH, MICHA R, IMAMURA F, PAN A, BIGGS ML, AJAZ O, DJOUSSE L, HU FB, MOZAFFARIAN D: Omega3 fatty acids and incident type 2 diabetes: a systematic review and meta-analysis. Br J Nutr 107 (Suppl 2): S214-S227, 2012b.

WU JH, CAHILL LE, MOZAFFARIAN D: Effect of fish oil on circulating adiponectin: a systematic review and metaanalysis of randomized controlled trials. J Clin Endocrinol Metab 98: 2451-2459, 2013.

YAMAUCHI T, KAMON J, MINOKOSHI Y, ITO Y, WAKI H, UCHIDA S, YAMASHITA S, NODA M, KITA S, UEKI K, ETO K, AKANUMA Y, FROGUEL P, FOUFELLE F, FERRE P, CARLING D, KIMURA S, NAGAI R, KAHN BB, KADOWAKI T: Adiponectin stimulates glucose utilization and fatty-acid oxidation by activating AMP-activated protein kinase1. Nat Med 8: 1288-1295, 2002.

ZHANG M, PICARD-DELAND E, MARETTE A: Fish and marine omega-3 polyunsatured fatty acid consumption and incidence of type 2 diabetes: a systematic review and meta-analysis. Int J Endocrinol 2013: 501015, 2013.

ZHENG JS, HUANG T, YANG J, FU YQ, LI D: Marine n-3 polyunsaturated fatty acids are inversely associated with risk of type 2 diabetes in Asians: a systematic review and meta-analysis. PLoS One 7: e44525, 2012. 